\title{
World-Wide Comparative Evidence for Calquing of Valency Patterns in Creoles
}

\author{
Susanne Maria Michaelis \\ Leipzig University and Max Planck Institute for the Science \\ of Human History (Jena) \\ susanne.michaelis@uni-leipzig.de
}

\begin{abstract}
Creole languages consistently show valency patterns that cannot be traced back to their lexifier languages, but derive from their substrate languages. In this paper, I start out from the observation that a convincing case for substrate influence can be made by adopting a world-wide comparative approach. If there are recurrent matches between substrate and creole structures in a given construction type, in creoles of different world regions and with different substrates, then we can exclude the possibility of an accident, and substrate influence is the only explanation. The construction types that I will look at are ditransitive constructions (Section 3), weather constructions (Section 4), experiencer constructions (Section 5), and motion constructions (Section 6). I will draw on the unique typological data source from the Atlas of Pidgin and Creole Language Structures (Michaelis et al., 2013a; 2013b). My conclusion is that the data provided in APiCS support the claim that during creolization, valency patterns have been systematically calqued into the nascent creoles.
\end{abstract}

\section{Keywords}

Creole languages - comparative creole approach - calquing of substrate patterns bi-clan sampling

\section{Introduction}

Creole languages mainly evolved in the context of European colonial expansion during the $16^{\text {th }}$ through $19^{\text {th }}$ centuries when a European colonial language,

(C) SUSANNE MARIA MICHAELIS, 2019 | DOI 10.1163/19552629-20190001

This is an open access article distributed under the terms of the prevailing CC-BY-NC License at the time of publication. 
the lexifier language, mixed with different labor-force languages spoken by the slaves or indentured laborers, the substrate languages. Creole languages overwhelmingly show lexical material from the European lexifier languages. In Seychelles Creole, for instance, over $90 \%$ of the verbs stem from dialectal $18^{\text {th }}$ century French varieties: donnen 'give' < French donner, koze 'speak' < French causer, and gete 'watch' < French guetter, bezwen 'need' < French (avoir) besoin $(d e)$. However, I will show in this paper that creole languages consistently show valency patterns that cannot be traced back to their lexifier languages, but derive from their substrate languages.

Substrate influence in creoles has been discussed by various authors (e.g. Alleyne, 1980; Boretzky, 1983; Holm, 1988; Lefebvre, 1998; Lefebvre (ed.), 2011; Lefebvre, 2015; McWhorter, 1997; Parkvall, 2000; Siegel, 1999; Siegel, 2008; Winford and Migge, 2007), but they have focused on specific constructions, on specific creole languages and/or specific substrate languages. Such claims are often plausible but they do not convince all creolists as there are typically also plausible alternative explanations in terms of the lexifier or universal tendencies. Claims of substrate effects are most convincing when the substrate feature is very rare cross-linguistically (see also Parkvall, 2000) and does not occur in the lexifier. A well-known example is the trial number in Tok Pisin personal pronouns (yumitripela 'the three of us'), which was calqued on an Oceanic substrate language (Smith and Siegel, 2013b: 217).

In this paper, I start out from the observation that a convincing case for substrate influence can also be made by adopting a world-wide comparative approach. If there are recurrent matches between substrate and creole structures in a given construction type, in creoles of different world regions and with different substrates, then we can exclude the possibility of an accident, and substrate influence is the only explanation. ${ }^{1}$

We will see that in the domain of valency, creoles show a substantial amount of constructional calquing from their substrates. The construction types that I will look at are ditransitive constructions (Section 3), weather constructions (Section 4), experiencer constructions (Section 5), and motion constructions (Section 6).

I will draw on typological data from the Atlas of Pidgin and Creole Language Structures (Michaelis et al., 2013a, 2013b), the World Atlas of Language Structures (Haspelmath et al., 2005; Dryer and Haspelmath, 2013), and other

1 A study that makes this argument is Michaelis and Haspelmath (2003) on ditransitive constructions, and McWhorter (1997: 35-39) similarly argues for substrate influence in a wide range of serial verb constructions for Atlantic and non-Atlantic creoles. 
typologically relevant data where necessary. My conclusion is that the data provided in APiCS support the claim that during creolization, valency patterns have been systematically calqued into the nascent creoles.

In each section, I will contrast the creole patterns with both the lexifier and substrate patterns to demonstrate how closely the creoles imitate the valency patterns of their substrates (or adstrates) instead of continuing the patterns of their lexifier languages. The analyzed data allow an even more far-reaching claim, namely that the creators of creole languages have not only imitated some valency patterns, but the semantic construal patterns of their dominant (native) languages. A creole construction 'Rain falls' may seem not to be dramatically different from the canonical European lexifier construction '(It) rains'. But the fact that in the creole the weather event is coded in subject position combined with some general verb, whereas in the European languages the event is coded in the verb with an expletive subject pronoun (in English: it rains, and French: il pleut), means that the whole framing of the weather event is crucially different in both sets of languages. Some creolists may prefer to explain such a difference in construction in terms of transparency and/or (semantic/syntactic) simplicity. But a closer and typologically informed look at the data will uncover that the reason why creole languages show these valency patterns is systematic constructional calquing of the substrate/adstrate patterns.

Before I discuss the four different construction types, I will briefly present the source of the creole data used in this study in Section 2.

The present paper is based on the Atlas of Pidgin and Creole Language Structures (APiCS, Michaelis et al., 2013a, 2013b), a large-scale comparative database of grammatical patterns in pidgins, creoles and mixed languages. In APiCS, 76 contact languages world-wide are investigated with respect to 130 structural features, some 330 segmental features, and 28 sociolinguistic features. As Map 1 illustrates, APiCS covers all major world regions. Compared to other existing cross-creole studies (e.g. Holm and Patrick, 2007; Parkvall, 2008), APiCS comprises information on a substantial number of non-Atlantic contact languages in South Asia, Southeast Asia, Melanesia, and Australia. It also contains contact languages which have non-European base languages, like Arabic, Bantu, and Malay.

In contrast to the World Atlas of Language Structures (WALS, Haspelmath et al., 2005; Dryer and Haspelmath, 2013), APiCS follows an expert-based 


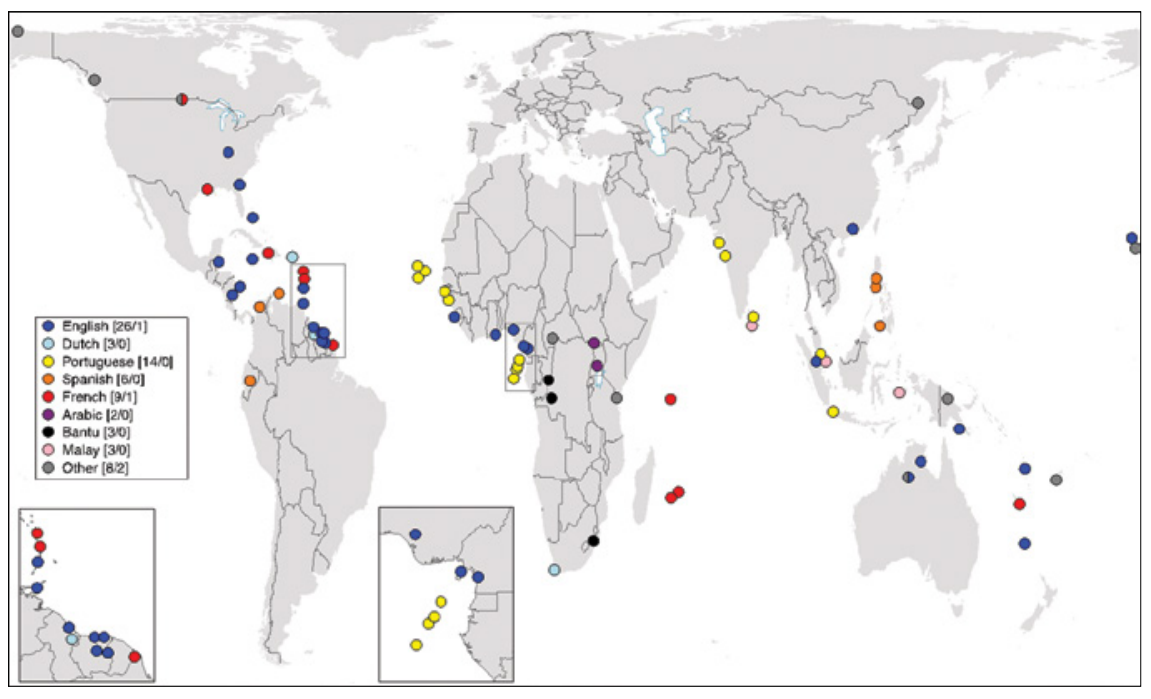

MAP $1 \quad 76$ contact languages in $\mathrm{APiCS}^{2}$

typology-approach: ${ }^{3}$ Each language expert or team of experts has filled in a structure questionnaire designed by the four editors (Michaelis, Maurer, Haspelmath, and Huber) by choosing feature values and giving examples which illustrate the value assignment. APiCS has been published as a four volume print work: the first volume displays chapters written by the four editors on each of the 130 structural features with the corresponding map where each coloured dot represents the given feature value for a given language, and the three other volumes constitute the Survey of pidgin and creole languages where each expert gives a concise overview of the social history, sociolinguistic situation and the grammar of the contact language. Besides the paper publication, the underlying database APiCS Online has been published electronically with open access (apics-online.info), with more than 15,00o fully glossed and translated examples as well as many references. 48 structural features of APiCS have been taken over from WALS. This gives us the unique possibility to see

2 For space reasons, the labels of the languages cannot be given in the map. For a list of the languages, see APiCS Online http://apics-online.info/contributions\#2/30.3/10.0. Mixed languages are represented by a pie-chart of the two contributing languages, e.g. Michif, a mixed language of Northern America, has half a red dot for the French component, and half a grey dot for "other", in this case Cree.

3 See also other CLLD-database publications with this same approach (http://clld.org/datasets .html), The World Loanword Database, The Electronic World Atlas of Varieties of English. 
the APiCS languages against the background of languages world-wide. APiCS Online provides special views for this comparison. ${ }^{4}$

It is noteworthy that creolists have made only little use of the typological wealth presented in WALS (but see Bakker et al., 2011; Daval-Markussen, 2014; and Velupillai, 2015 on quantitative comparisons). This may be due to different reasons: The majority of creolists are language specialists, and only a small minority of them is interested in broad language comparison. Furthermore, the discussion has been centered around the question whether mainly (or solely) substrates or lexifiers or universals have shaped creoles (see e.g. Muysken and Smith, 1986; Lefebvre, 1998; Chaudenson, 1991; Mufwene, 2001). But much less attention has been paid to a solid qualitative comparison of historically unrelated creoles with their substrates and their lexifiers to eventually filter out which kind of features can be systematically traced back to substrates or lexifiers or universal processes during creolization. I think that with WALS and other typological studies at hand, and the publication of APiCS a new round of meticulous qualitative - and not only quantitative - language comparison has been opened up.

This article is meant to be a starting point for such a qualitative, data-based re-evaluation of the role of the contributing languages and universal features in the process of creolization.

In my view, every theory of pidginization and creolization should base itself on such a fine-grained data-driven study on the world-wide variation of creole languages and non-creole languages to make any significant claims about creole languages in general. Even more so if far-reaching universal and/or cognitive processes are invoked.

In the following sections, I will discuss four construction types in the 59 creoles in APiCS. I use the term "creole" for classical creoles like Saramaccan, Mauritian Creole, and Tayo, but also pidgincreoles, i.e. expanded pidgins that are used in a wider set of linguistic functions even though they are not the mother tongues of all their speakers, such as Cameroon Pidgin English or Tok Pisin (Bakker, 2008: 131ff, who takes this term from Philip Baker).

As for the cross-linguistic data available for the four construction types, it is only ditransitive constructions with the verb 'give' (section 3) that are covered by WALS. But weather constructions with rain (section 4) have been analysed by a series of typological studies, e.g. by Eriksen et al. (2010, 2012), and Velupillai (2012). For motion-to/motion-from constructions (section 4), we have an excellent typological study by Wälchli and Zuñiga (2006), which I will rely on.

4 All APiCS maps in this paper were designed by Hans-Jörg Bibiko, Max Planck Institute for the Science of Human History (Jena). 
Unfortunately, there are no large-scale typological surveys for experiencer constructions (section 6). Nevertheless, I have tried to collect the available typological information for the construction under discussion.

3

\section{Ditransitive Constructions}

\subsection{Ditransitive Constructions in APiCS Creoles}

The first construction type that I will discuss in this paper is DITRANSITIVE CONSTRUCTIONS. Such constructions involve a verb of physical or mental transfer with three participants: an agent, a recipient, and a theme. Following the APiCS chapter (Haspelmath et al., 2013), I will only look at the most frequent physical transfer verb 'give', as constructions with other ditransitive verbs may show considerable variation. Furthermore word order will not be considered. Examples (1) and (2) feature a double-object construction, with no preposition marking either recipient or theme (corresponding to the same coding of the patient in a monotransitive clause).

(1) Krio (English-based; Finney, 2013)

di uman gi di titi som moni

the woman give the girl some money

REC THEME

'The woman gave the girl some money.'

(2) Seychelles Creole (French-based; Michaelis and Rosalie, 2013)

$\begin{array}{llllll}\text { Mon } & n & \text { donn } & \text { Marcel en mang. } \\ \text { ISG } & \text { PRF } & \text { give } & \text { Marcel } & \text { a mango } \\ & & & \text { REC } & \text { THEME }\end{array}$

'I gave Marcel a mango.'

Examples (3) and (4) show an indirect-object construction where the recipient is marked by a special preposition (contrasting with the identical marking of theme and patient in a monotransitive clause), $k u$ in Papiá Kristang and long in Tok Pisin.

(3) Papiá Kristang (Portuguese-based; Baxter, 2013)

$\begin{array}{lllllllll}\text { eli } & \text { sa } & \text { tiu } & j a & \text { bendé } & \text { aké } & \text { prau } & k u & \text { yo } \\ \text { 3SG } & \text { GEN } & \text { uncle } & \text { PFV } & \text { sell } & \text { that } & \text { boat } & \text { DAT } & \text { 1SG } \\ & & & & & \text { THEME } & & \text { REC } & \end{array}$

'His uncle sold the boat to me.' 
(4) Tok Pisin (English-based; Smith and Siegel, 2013a)

$\begin{array}{llllll}\text { Givim } & \text { mani } & \text { long } & \text { papa bilong } & y u \text {. } \\ \text { give } & \text { money } & \text { PREP } & \text { father } & \text { POSS } & \text { 2SG } \\ & \text { THEME } & \text { REC } & & & \end{array}$

'Give your father the money'

It has been claimed that creoles typically show double-object constructions (Bickerton, 1995: 1453; Bruyn et al., 1999) even if their lexifiers, for instance the Romance languages, have an indirect-object construction (e.g. French J'ai donné une mangue à Marcel. 'I gave Marcel a mango'). But if we look at the worldwide distribution of creoles in APiCS, the picture is not uniform at all (Map 2).

First of all, creole languages can have both construction types, doubleobject constructions (blue dots) and indirect-object constructions (red dots), ${ }^{5}$ which is shown in the pie-charts on Map 2. But if for simplicity we restrict ourselves to creoles with only double-object constructions and creoles with only indirect-object constructions, that is creoles shown by single-coloured dots, the figures are as follows: 6

Indeed, as shown in Table 1a, a clear majority of APiCS creoles (69\%) feature the double-object construction, whereas only a third of APiCS creoles show the indirect-object construction as in (3-4). But this is not the full story. A quick look at Map 2 reveals two important points,

(i) There is a clear areal pattern: Blue and red dots are not randomly distributed. On the contrary: We see coherent areas of uniform marking. Atlantic creoles (i.e. creoles spoken in West Africa and the Caribbean) and French Indian Ocean creoles show the double-object construction, whereas the indirect-object construction predominates in Central Africa, South Asia, insular Southeast Asia, the Philippines, Australia and Melanesia;

(ii) There is a different density of sampled languages in different parts of the world: In the Atlantic, there are many more dots than in the Indian Ocean, Southeast Asia and the Pacific.

Moreover, many of the Atlantic creoles are historically closely related to each other. Creolists have been misled to infer from this majority of related creoles that their majority pattern, here the double-object construction, is a universal feature of creoles (see e.g. Bickerton, 1995: 1453 and Bruyn et al., 1999 cited

5 We do not investigate the secondary-object construction due to its marginal status in the contact languages that are studied here.

6 For the full picture, see Michaelis and Haspelmath (2003) and Haspelmath et al. (2013). 


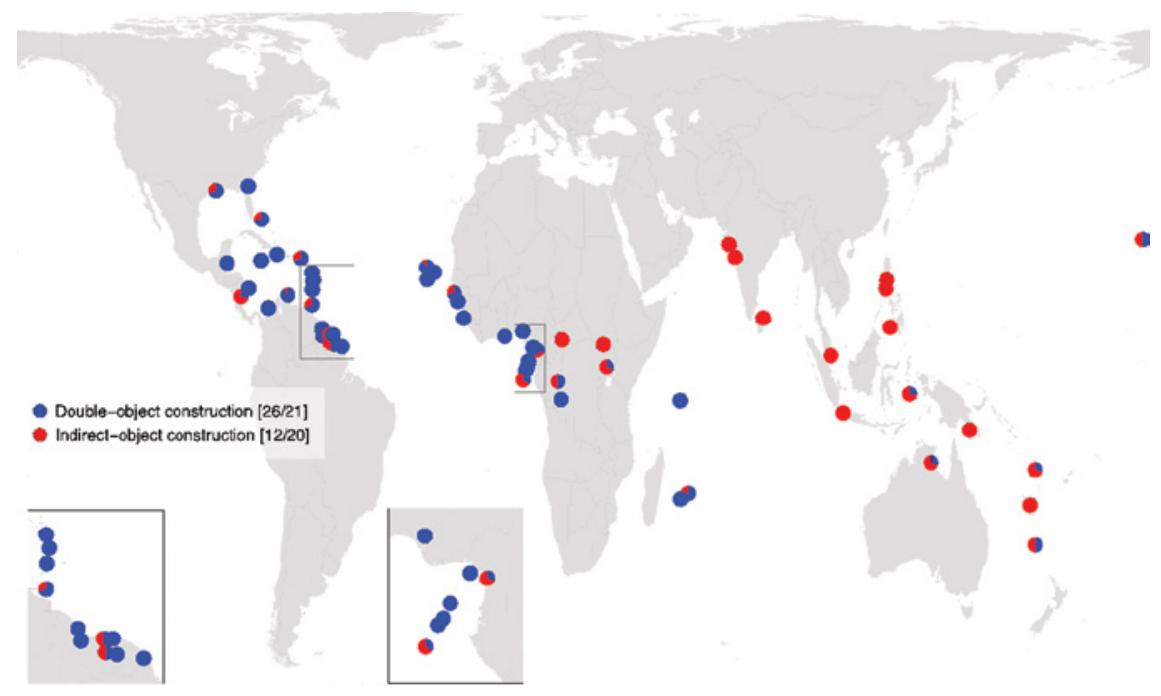

MAP 2 Ditransitive constructions with 'give' in 59 creoles of APiCS (based on Haspelmath et al., 2013); the numbers in brackets refer to the number of creoles which show the feature value in question, e.g. 26 creoles in APiCS exclusively have double-object constructions, and 21 creoles share this construction with the indirect-object construction, the pie-charts reflecting the relative importance of each feature value.

TABLE 1A Ditransitive constructions in creoles (exclusive values only)

\section{APiCS creoles}

\begin{tabular}{lrr}
\hline Double-object constructions & 26 & $69 \%$ \\
Indirect-object constructions & 12 & $31 \%$ \\
Total & 38 & $100 \%$ \\
\hline
\end{tabular}

above). Therefore if we want to say something about creoles in general, and not just about Atlantic creoles, we need a method to control for genealogical and areal relatedness of these languages. For this reason I propose the so-called BI-CLAN sampling method, which I will briefly introduce in the next subsection. For a detailed discussion of this approach, see Michaelis (2017).

\subsection{Bi-Clan Sampling of Creoles}

Each creole evolved historically from at least two contributing languages, a lexifier and a substrate (or a set of substrates). For instance, English-based Atlantic creoles, i.e. languages like Jamaican, Trinidad English Creole, Sranan, and Krio, are historically much more closely related to each other than, for 
instance, Jamaican is related to Tok Pisin. The former all stem from an encounter of English dialectal varieties of the $17^{\text {th }} / 18^{\text {th }}$ centuries and African languages of the so-called Macro-Sudan Belt (see Güldemann, 2010). ${ }^{7}$ Tok Pisin, too, is an English-based creole, but compared to the Atlantic creoles just mentioned, it has very different substrate/adstrate languages, namely Oceanic and Papuan languages of Melanesia. In order to assess these different historical profiles of the various creoles and to control for genealogical and areal relatedness of both the substrate(s) and the lexifier, I propose a new sampling method, which is based on groups of closely related languages called BI-CLANS. A CLAN ${ }^{8}$ is a language or a family or a linguistic area, and a BI-CLAN is a combination of a lexifier clan and a substrate/adstrate clan. For example, the lexifier clan "English" combined with the substrate clan "Macro-Sudan" gives rise to the bi-clan "English/Macro-Sudan", which comprises creoles such as Jamaican, Sranan, Saramaccan, Trinidad Creole English, Gullah, Bahamian, San Andres Creole etc. The sampling method works as follows: If two languages belonging to the same bi-clan show the same feature value, they are not counted separately. ${ }^{9}$ The need for such a new sampling method in creole studies has become obvious because all available current samples of creole languages (Holm and Patrick, 2007; Parkvall, 2008; eWAVE, 2011; APiCS, 2013) are heavily biased towards one major historical group of creoles, namely Atlantic creoles. These creoles have arisen via the contact between some very closely related Western European lexifier languages, namely English, Dutch, French, Portuguese, and Spanish, and a group of West African Niger-Congo substrate languages, which stretch over several different language families, but nevertheless due to longstanding language contact show clear patterns of structural convergence (see Güldemann, 2010). Given the numerical overrepresentation of one group of historically closely related creoles, i.e. Atlantic or more precisely European/ Macro-Sudan creoles, the bi-clan approach then reduces the genealogical

7 The situation is actually more complex than this because there are sometimes specific historical links between creole languages, for instance where a new island was settled from a creole-speaking island (cf. Seychelles Creole, which is an offspring of Mauritian Creole). Cf. also Huber (1999) on the settlement of Freetown, Sierra Leone, from the New World (Nova Scotian settlers and Jamaican Maroons).

8 The term "clan" was suggested to me by Bernard Comrie.

9 A similar approach was adopted by Dryer $(1989,1992)$ for world-wide samples in the study of language universals. Dryer suggests the unit genus, which is a level between the individual language and the larger family. A typical example of genera are the subfamilies of IndoEuropean, e.g. Germanic, Slavic, Celtic, Romance. Dryer's unit genus represents a similar level of granularity between the individual language and the larger family. 
and areal predominance of Atlantic creoles in a principled way to account for the world-wide diversity of creoles. Such an approach is necessary if we want to generalize over creoles in general, and not just over one set of historically closely related creoles.

With this explication of bi-clan sampling, we can go back to the ditransitive constructions in creoles and look at the bi-clan distribution of double-object and indirect-object constructions.

\subsection{Ditransitive Constructions in the Bi-Clan Distribution}

Creole languages of the same bi-clan are genealogically (and/or areally) closely related, so they are likely to show similar typological profiles. This means that languages of the same bi-clan often show the same feature value for a given feature. Table $\mathrm{ib}$ shows the figures of the distribution of double-object and indirect-object constructions in the APiCS creoles together with the distribution of the two constructions in the different APiCS bi-clans.

In the present feature, for instance, all 10 creoles from the English/MacroSudan bi-clan show the double-object construction (only concentrating on exclusively double-object constructions represented by single-coloured blue dots on Map 2). ${ }^{10}$ However, no creole from the English/Macro-Sudan bi-clan shows exclusively indirect-object constructions. Such an overall distribution of creoles from the same bi-clan is what we expect from genealogically/areally related languages, namely that they share many linguistic features. The 10 instances of uniform marking (i.e. double-object construction) should therefore not be given the same weight as other creoles with no close relatives. Thus, in the bi-clan distribution, a bi-clan is counted only once if its members show uniform behavior. The English/Macro-Sudan creoles in Table $1 b$ thus contribute 10 points to the language count, but only one point to the bi-clan count.

TABLE 1B Ditransitive constructions in creoles (exclusive values only) with bi-clan distribution

\section{APiCS creoles APiCS bi-clans of creoles}

\begin{tabular}{lrrrr}
\hline Double-object constructions & 26 & $69 \%$ & 9 & $\mathbf{5 6 \%}$ \\
Indirect-object constructions & 12 & $31 \%$ & 7 & $\mathbf{4 4 \%}$ \\
Total & 38 & $100 \%$ & 16 & $100 \%$ \\
\hline
\end{tabular}

10 The other 7 creoles from the English/Macro-Sudan bi-clan also predominantly feature the double-object constructions with indirect-object constructions as a minor option (compare the small red slices in the pie-charts on Map 2). 
Of the five languages that belong to the French/Macro-Sudan bi-clan, four have double-object constructions, whereas one creole (Louisiana Creole, and here a special geographical variety of Pointe Coupee, Neumann-Holzschuh and Klingler, 2013) features the indirect-object construction. Therefore, this bi-clan is counted twice, once for the existence of the double-object construction and once for the existence of the indirect-object construction. In this way, we capture the linguistic diversity within and across bi-clans. The advantage of this method is straightforward: Bi-clans are treated alike independently of their size - bi-clans with few creoles have the same impact as bi-clans with many more creoles. The crucial criterion is whether the creoles of one and the same bi-clan show the same or different feature values.

If we now apply the bi-clan distribution to all $\mathrm{APiCS}$ creoles as displayed in Table $1 b$, the majority of double-object marking creoles shrinks and we have a nearly equal split between creoles with exclusively double-object constructions $(56 \%)$ and those with exclusively indirect-object constructions $(44 \%)$, as shown in Table $1 \mathrm{~b}$. Here the bi-clan subdivision shows that the indirect-object construction is not a minor pattern within creoles world-wide, but also constitutes a well-represented construction type of the world's creoles.

\subsection{Substrate Patterns in Ditransitive Constructions}

As mentioned earlier, there is a clear-cut geographical distribution of the two constructions between on the one hand Atlantic and French Indian Ocean creoles, and on the other hand South Asian, Southeast Asian and Pacific creoles. This division does not correlate with lexifier languages as, for instance, English/ Macro-Sudan creoles show double-object constructions, whereas English/ Oceanic creoles (Tok Pisin and Bislama) show indirect-object constructions. The same is true for other European lexifiers. Portuguese/Macro-Sudan creoles (Santome, Principense, Angolar) show double-object constructions, whereas Portuguese/Indic (Diu-Indo Portuguese, Korlai, Sri Lanka Portuguese) and Portuguese/Malay creoles (Papiá Kristang, Batavia Creole) show indirectobject constructions. Once we compare the creole data to the corresponding WALS data, we clearly see that it is the substrates/adstrates which determine the creole patterns. I will first look at the languages of Africa.

In Map 3, we see that in sub-Saharan Africa, the clear majority of languages show the double-object construction, as examples $\left(5^{-6}\right)$ illustrate.

(5) Wolof (Atlantic; Creissels, 2005: 63)

$\begin{array}{llllll}\text { Dama-y } & \text { jox } & \text { ganaar } & \text { gi } & \text { dugub } & j i \\ \text { VFOC.SM 1SG-TAM } & \text { give } & \text { hen } & \text { DEF } & \text { millet } & \text { DEF } \\ & & \text { REC } & & \text { THEME }\end{array}$

'I'm giving the millet to the hen.' 


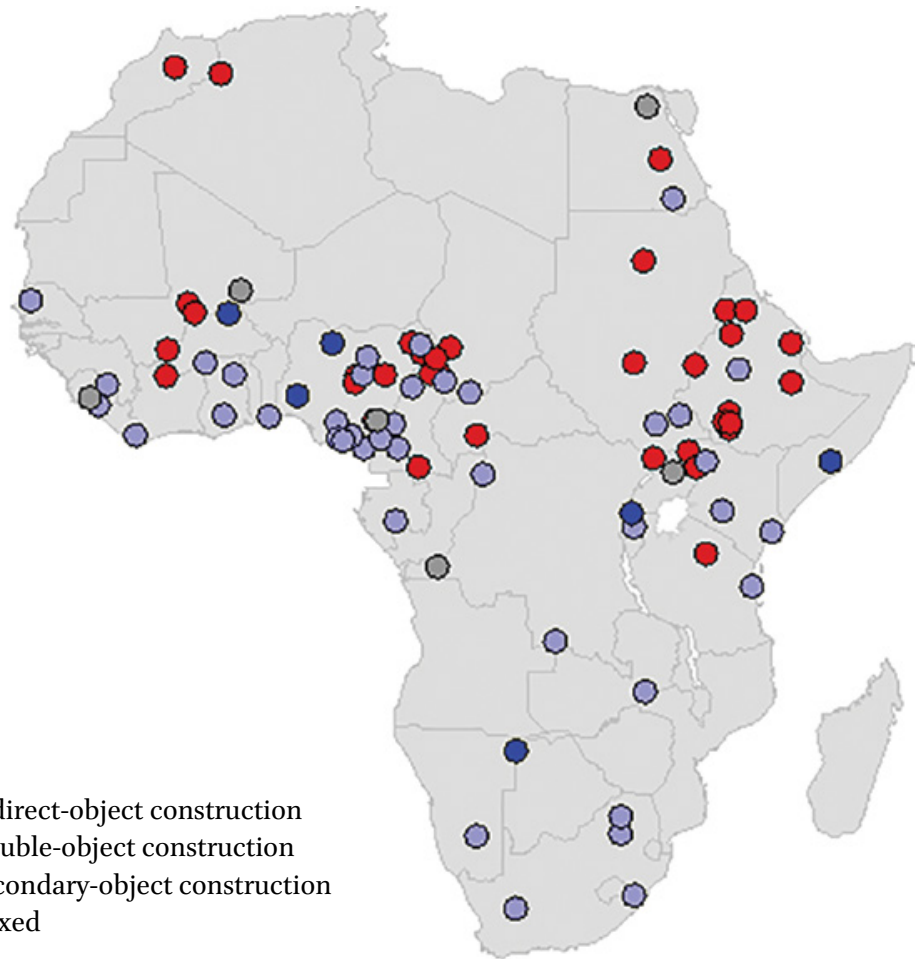

MAP 3 Ditransitive Constructions: The Verb 'Give' (Haspelmath, 2013)

(6) Fongbe (Kwa; Lefebvre and Brousseau, 2002: 254)

Kòkú ná Asíbà àsón

Koku give Asiba crab

REC THEME

'Koku gave Asiba (some) crab).'11

Most of the languages on Map 3 are from western Africa and central-eastern Africa, because in these areas the diversity is far greater than in the south. Almost all of central-southern Africa is occupied by closely related Bantu languages, and these all show double-object constructions, so adding new dots would not add much new information. We do see three areas where the indirect-object construction is predominant: in Ethiopia, Semitic and Cushitic languages tend to show indirect-object constructions, and in Mali, the Mande languages tend to show indirect-object constructions. But these are all

11 Lefebvre and Brousseau (2002: 254) note that the linearization THEME RECIPIENT is equally possible. 


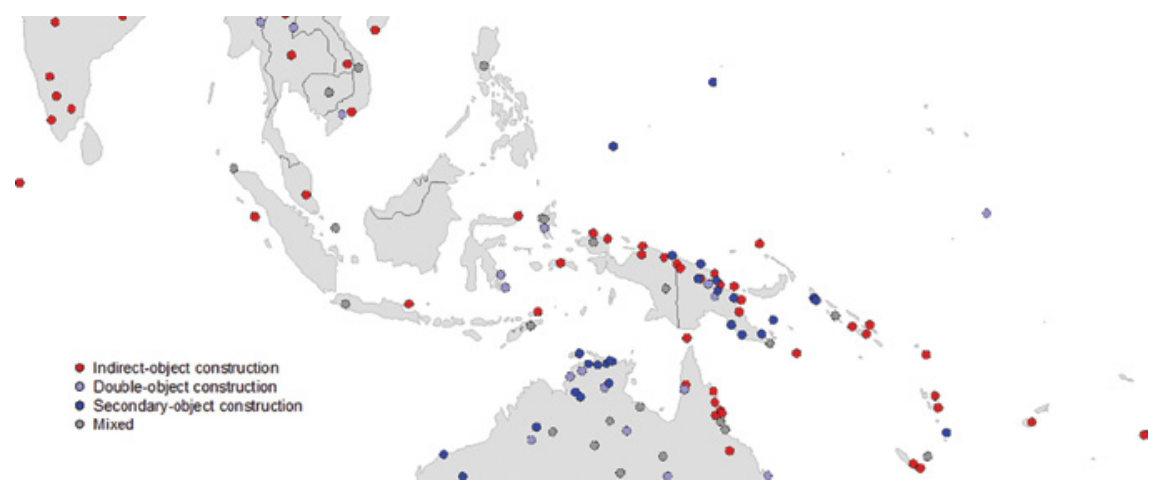

MAP 4 Ditransitive Constructions: The Verb 'Give' (Haspelmath, 2013)

interior regions - note that the coastal regions have exclusively double-object languages. Indeed, these are precisely the regions where most of the slaves which were deported to the various islands close to West and East Africa and the Caribbean came from.

If we now consider the substrate/adstrate languages from South Asia, insular Southeast Asia and the Pacific, which are relevant for the corresponding APiCS creoles, it is the indirect-object construction which predominates in these regions (see Map 4 and examples in (7)-(8)).

(7) Kwaio (Oceanic; Keesing, 1985: 30)

$\begin{array}{llllll}\text { 'E-meru } & \text { meru } & k w a t e-a & \text { boo } & \text { ba'ita } & \text { fa-na. } \\ \text { we } & \text { 1PL.SUBJ } & \text { give-3SG.OBJ } & \text { pig } & \text { big } & \text { for-3SG } \\ & & & \text { THEME } & \text { REC }\end{array}$

'We gave him a pig.'

(8) Riau Indonesian (Malayic; Gil, p.c.)

$\begin{array}{llllll}\text { Kenapa } & \text { David tak kasi ikan sama dia. } \\ \text { why } & \text { David neg give fish } & \text { with him/her } \\ & & & & \text { THEME } & \text { REC }\end{array}$

'Why didn't you (David) give her the fish?'

As the Romance lexifiers show the indirect-object construction, too, one may want to argue for convergence or reinforcement of the lexifers' and the substrates' (or adstrates') pattern (e.g. for Portuguese-based Korlai and Frenchbased Tayo). But English-based Tok Pisin (see example 4) is striking in this perspective because here only the indirect-object construction is present reflecting its Oceanic substrates against indirect-object and double-object 
constructions in its lexifier English - whereas no Atlantic English-based creole has only the indirect-object construction.

Considering these data, I would like to claim (following Michaelis and Haspelmath, 2003) that in ditransitive constructions, creoles clearly reflect their substrate/adstrate pattern against possibly conflicting patterns in their lexifiers.

Of course, the strongest evidence for substrates comes from features that are not only absent in the creoles's lexifiers, but also rare in the world's languages. The double-object construction is in fact very common in the world's languages, but the indirect-object construction is about equally common (as can be seen from Haspelmath, 2013). However, what makes the present case (and the other constructions still to be discussed) relatively strong is the fact that the explanation works for a large number of creoles, and that the crosslinguistic picture of ditransitive constructions is unusually rich due to the typological data available in WALS.

\section{Weather Constructions: 'Raining'}

\subsection{Weather Constructions: 'Raining' in APiCS Creoles}

The second construction type under investigation concerns a specific meteorological event, namely RAINING. Meteorological events are not expressed uniformly across languages (cf. Eriksen et al., 2010; 2012, and Velupillai, 2012 for recent cross-linguistic studies), and weather constructions also exhibit interesting variation in the creole languages in APiCS. Since languages often code different meteorological events with different syntactic constructions ('the sun is shining', 'it is raining', 'there is a thunderstorm', etc.), I consider exclusively the situation 'it is raining. ${ }^{12}$ English and French show constructions with an expletive subject pronoun, as in it is raining, il pleut. However, by far the most common type in the creole languages in APiCS is represented by a construction where raining is expressed by a word referring to the natural element 'rain' or 'water' in subject position, accompanied by a general verb such as 'fall' or 'hit': 'rain falls' (see value 1, blue dots on Map 5) as illustrated in examples (9)-(12).

Some creoles have more than one raining construction, represented as slices of a pie-chart according to their relative importance, as Map 5 shows.

12 See the corresponding APiCS chapter Michaelis and APiCS Consortium (2013a). 


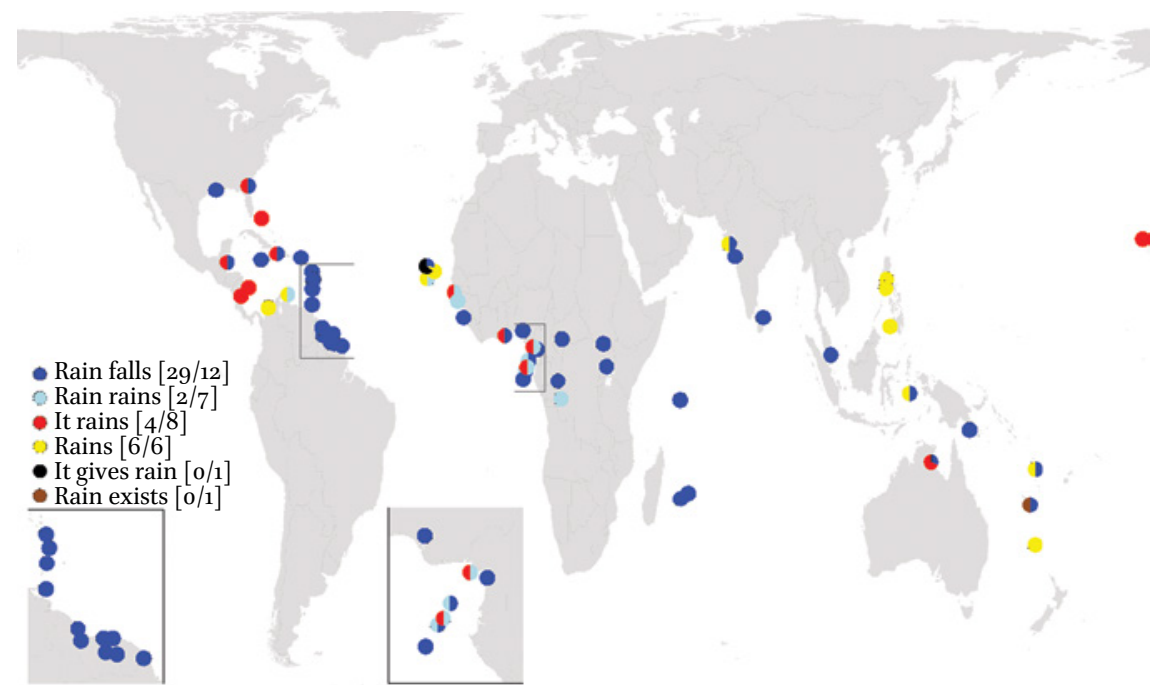

MAP 5 Raining constructions in 59 creoles of APiCS (Michaelis and APiCS Consortium 2013a)

(9) Haitian Creole (French-based, Caribbean; Fattier, 2013)

Lapli a pral tonbe talè.

Rain DEF FUT.go fall soon

'It will rain very soon.' (lit. 'Rain will fall soon.')

(10) Early Sranan (English-based, Caribbean; van den Berg and Bruyn, 2013)

Areen fadomm.

rain fall

'It is raining.' (lit. 'Rain is falling.')

(11) Mauritian Creole (French-based, Indian Ocean; Baker and Kriegel, 2013)

lapli pe tombe

rain PROG fall

'It is raining.' (lit. 'Rain is falling.')

(12) Tayo (French-based, Pacific; Ehrhart and Revis, 2013)

lapli le to:mbe

rain si fall

'It is raining.' (lit. 'Rain is falling.')

It seems that the 'rain falls' construction is not areally restricted, as we find it spread over many different regions of the world in creoles based on various 
lexifier languages. But as we will see in the more detailed discussion of this feature below, it is very likely that we can detect substrate influence in this feature, too. Unfortunately, raining constructions are not covered by WALS, but Velupillai (2012: 257ff.) presents cross-linguistic data on raining constructions in 218 languages world-wide, which will be the basis for our comparison with non-creole languages.

A very similar construction type to the one in (9)-(12) is illustrated by example (13), where a 'rain' noun in subject position is combined with a 'rain' verb, i.e. a verb that exclusively (apart from metaphorical usages) refers to raining situations. Only few creole languages show this construction.

(13) Guinea-Bissau Creole (Portuguese-based; Intumbo et al., 2013)

Tcuba na tcubi.

Rain PROG rain

'It is raining.'

Here, the geographical restriction to Africa (and some nearby islands) is striking. Besides Kikongo-Kituba and Guinea-Bissau Kriyol, which have only this 'raining' construction, it is found as one option in Cape Verdean Creole of Brava, Casamancese Creole, Pichi, the three Gulf of Guinea creoles Principense, Santome, and Angolar, and Papiamentu, the only Caribbean creole with this construction outside of Africa.

The third construction type ('it rains') consist of an expletive subject and a 'rain' verb, as is well documented in Western European languages like English (it rains), French (il pleut), and Dutch (het regent).

(14) Gullah (English-based; Klein, 2013)

$E$ ain rain fa shree yeaah an six mont. 3SG.SBJ NEG.AUX rain for three years and six months 'It had not rained for three years and six months.' (Lk 4.25)

Interestingly, most of the 12 languages with this value are English-based languages, and all four languages that have only this construction are also Englishbased languages (Bahamian Creole, Nicaraguan Creole English, San Andres Creole English, and Hawai'i Creole). These creoles can be classified as more acrolectal and as such more closely reflecting the English expletive construction. But some Portuguese-based languages too (Santome, Guinea-Bissau Kriyol, Casamancese Creole) have the construction with an expletive subject, even though their lexifier Portuguese does not show an expletive subject in the corresponding construction (chove 'it rains'): 
(15) Santome (Portuguese-based; Hagemeijer, 2013)

$\hat{E} \quad k a$ sôbê muntu fan.

3SG IPFV rain a.lot PCL

'It rains a lot!'

In the last construction type, there is just a 'rain' verb without any subject (as in Spanish llueve and Portuguese chove 'it rains').

(16) Ternate Chabacano (Spanish-based; Sippola, 2013)

Ta yobé.

IPFV rain.V

'It rains'. OR: 'It's raining.'

(17) Ambon Malay (Malay-based; Paauw, 2013)

Mo ujang.

FUT rain

'It's going to rain.'

Here, we again see some geographical patterning: The 12 creole languages with this value are spoken on the Cape Verde Islands, in Asia, and the Pacific, but not in mainland Africa, the Gulf of Guinea, the Caribbean (except for Papiamentu and Palenquero), or Australia.

Table 2 summarizes the distribution of the different raining constructions over the creoles in APiCS. Again, for simplicity reasons, we restrict ourselves to creoles with exclusive feature values, i.e. which only show one construction in this feature.

In the following subsection, I will contrast the APiCS data with the crosslinguistic data collected by Velupillai (2012) in order to check how well a potential substrate scenario can explain the distribution of creole patterns.

TABLE 2 Raining constructions in creoles (exclusive values only)

\begin{tabular}{lrrrr}
\hline & \multicolumn{2}{c}{ APiCS creoles } & \multicolumn{2}{c}{ APiCS bi-clans of creoles } \\
\hline rain falls & 29 & $70 \%$ & 13 & $\mathbf{6 1 \%}$ \\
rain rains & 2 & $5 \%$ & 2 & $10 \%$ \\
it rains & 4 & $10 \%$ & 2 & $10 \%$ \\
rains & 6 & $15 \%$ & 4 & $19 \%$ \\
total & 41 & $100 \%$ & 21 & $100 \%$ \\
& & & & \\
\hline
\end{tabular}




\subsection{Substrate Patterns in Weather Constructions: 'Raining'}

As we have seen before, the first APiCS construction 'rain falls' is by far the most widespread in creoles, and this holds in the bi-clan distribution, too (see Table 2). Out of the 16 creoles belonging to the English/Macro-Sudan bi-clan, for instance, 14 feature the 'rain falls' construction..$^{13}$ As there is no WALS chapter relating to raining construction, we rely on Eriksen et al. (2010) and (2012), who investigate weather constructions in some 30 languages of different world regions, and on Velupillai (2012), who looks at weather constructions in a world-wide sample of 218 languages (see Map 6).

Interestingly enough, nearly $60 \%$ of the world's languages in Velupillai's (2012) sample (128 out of 218 languages) show the 'rain falls/rain rains' construction, too. But again, if we have a closer look at Map 6, we see that this construction is not randomly distributed in the world's languages, but it can indeed be found in well circumscribed, coherent linguistic areas, e.g. in Subsaharan Africa, with the following African clans: Macro-Sudan, Bantu, and Ijo. Creolists like Koopman (1986) and Lefebvre (1998) have pointed out the

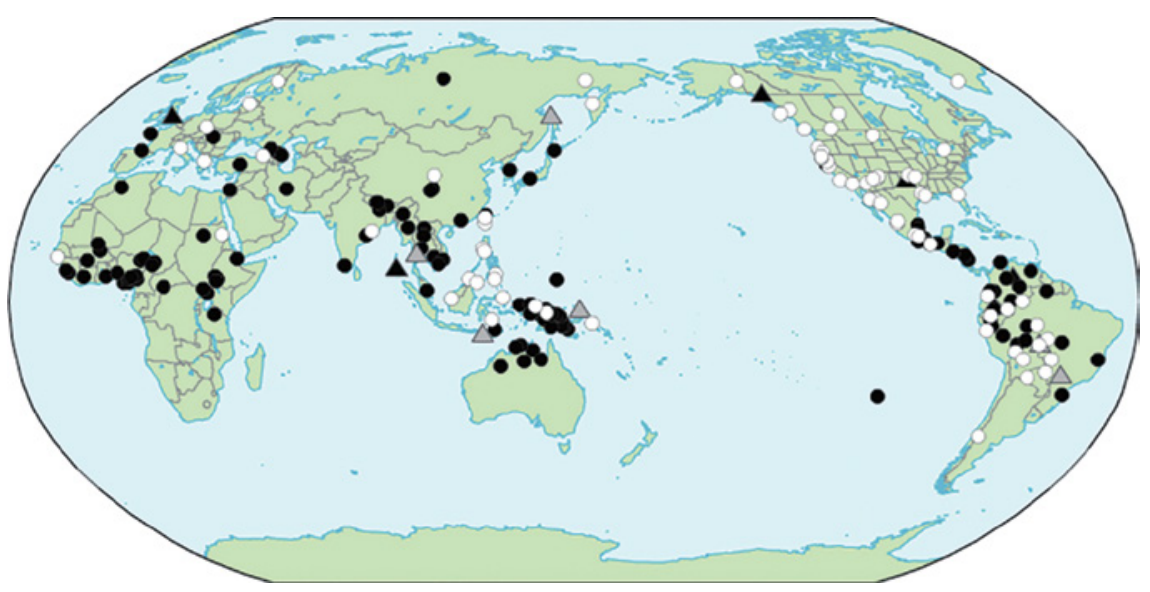

MAP 6 Weather constructions in 218 languages (Velupillai, 2012: 26o). ${ }^{14}$ Black triangles: 'it rains' (6 languages), grey triangles: '(there is) rain/rain exists' (6 languages), black dots: 'rain falls'/'rain rains'/'rain exists' (128 languages), white dots: 'rains' (78 languages) ${ }^{15}$

13 In some of these languages, the 'rain falls' construction is shared with the expletive construction 'it rains'.

14 The map is used with permission from the publisher https://www.benjamins.com/ \#catalog/books/z.176/mai.

15 I have adapted the names of Velupillai's feature values to the value names. APiCS feature values. Velupillai's original feature values are: black triangles 'dummy subject', grey triangles 'predicative noun', black dots 'referential subject', white dots 'avalent construction'. 
parallel syntactic constructions in West African languages, in particular in Fongbe, which is one of the most important substrates for Haitian Creole (cf. example 9) and other creoles in the Macro-Sudan clan:

(18) Fongbe (Kwa; Lefebvre and Brousseau, 2002: 245)

Jí jà

rain fall

'It is raining.' (lit. 'Rain is falling.')

Similar constructions are found in Bantu languages, giving rise to the same structures, for instance, in the French-based creoles of the Indian Ocean (see examples 11 from Mauritian Creole).

(19) Swahili (Bantu; Vitale, 1981: 57f.)

(Mvиa) i-na-nyesha.

(rain) 9-PRs-fall

'It is raining.' (lit. 'Rain is falling.')

As Map 6 illustrates, northern Australian languages overwhelmingly feature the 'rain falls' construction, too. For the Australian English-based creole language Kriol, Schultze-Berndt and Angelo (2013) therefore also argue for substrate influence in this construction type (rein bin-a bol-dan, [rain PST-POT fall-down] lit. 'rain falls'), as a similar construction is found in the traditional languages of the area: ${ }^{16}$

(20) Jaminjung (Mirndi, Northern Australia; Schultze-Berndt, 2013)

Gugu gardambiyang wirlarrungburru.

gugu ga-rda-m=biyang wirlarrung-burru

water 3 SG.S-fall-PRS=SEQ lightning-PROPR

'It is raining now (lit. 'water/rain falls'), with lightning.'

The same picture holds for Tok Pisin, Bislama, and Tayo which have Oceanic substrates which equally show 'rain falls' constructions:

(21) Mwotlap (Oceanic, Northern Vanuatu; François, 2001: 342)

Na-smal me-smal.

ART-rain PFV-rain

'It is raining.' (lit. 'Rain is raining')

16 See also Kofod (1978: 195) on Miriwung, East Kimberley. 
(22) Xârâcùù (Oceanic, New Caledonia; Moyse-Faurie, 2013)

kwiè $\quad x w a$

rain fall

'It rains.' (lit. 'Rain falls.')

But it is not only for the 'rain falls' type that I would like to postulate substrate influence, but also for the 'rains' type (yellow dots on Map 5 and white dots on Map 6). This coding type also forms linguistic areas. We find it in Southern and Eastern Europe, in the Americas, in large parts of insular Southeast Asia, and as it seems - in some areas of mainland Southeast Asia. Most importantly the 'rains' type is virtually absent from Subsaharan Africa (with some rare/minor exceptions, see Map 6).

(23) Tagalog (Malayo-Polynesian, Northern Philippines; Kroeger, 1993:49) umuulan

IPFV.rain

'It is raining.'

(24) Jakarta Indonesian (Malayo-Polynesian; Conners and Gil, 2013)

Ujan.

rain

'It's raining.'

(25) Mandarin Chinese (Sino-Tibetan; Zhang, 2013)

下雨了。

Xiàyǔle.

Xiayu le

rain PRS

'It is raining.'

Interestingly, APiCS creoles with substrate/adstrate languages from these areas equally show this construction type: all Chabacano varieties and Ambon Malay (see examples 16 and 17). As for the Chabacano varieties, one could claim that the 'rains' construction should be traced back to the Spanish lexifier (llueve 'it rains'). But here again a typologically informed look at other APiCS languages of the same area helps us to get a clearer picture: the two English-based languages Singlish and Chinese Pidgin English and Singapore Bazaar Malay also feature the 'rains' construction. As for the two English-based languages this is the case irrespectively of the fact that their lexifier language 
English has the 'it rains' construction with the expletive subject. ${ }^{17}$ Other APiCS pidgins in other areas of the world show the 'rain falls' construction. So it is not the case that APiCS pidgins in general show the 'rains' construction as a kind of simplified lexifier construction.

Therefore these additional data are again consistent with the claim that in "raining" constructions, too, the valency patterns of creoles (overwhelmingly) go back to their substrates/adstrates, and not to their lexifiers. The fact that in this construction type not only single creoles, but creole languages world-wide mirror their substrate pattern again strengthens my claim.

\section{Experiencer Constructions 'Headache'}

In this section, I will look at a third construction type in creole languages, EXPERIENCER CONSTRUCTIONS. As experiencer constructions vary significantly depending on the type of experience they express (e.g. pain, emotions, fear), I will concentrate on pain sensations and more specifically on situations which involve 'headache', as in English She has a headache (cf. the corresponding APiCS chapter Michaelis and APiCS Consortium, 2013b). Such constructions involve three participants, an experiencer who experiences the pain sensation ('she'), the sensation itself ('ache'), and potentially a body-part ('head') to which this sensation is related. There is a lot of interesting variation in such constructions. However, here I focus on the question which of the three participants is coded in subject position. Subject is defined here as an argument that is coded like the typical agent in a monotransitive clause, or the single argument of an intransitive clause.

Map 7 shows the distribution of the different types of 'headache' constructions in the 59 creoles in APiCS. If a language has more than one feature value, the different construction types are rendered as slices of a pie-chart according to their relative importance, as already shown in earlier maps. As one can see in Map 7, quite a few creoles show more than one construction type.

In the first construction type, which is well-known from the European lexifiers ('She has a headache', red dots on Map 7) the experiencer is coded as subject, as in examples (26) and (27). This type is fairly widespread among the APiCS languages.

17 Besides the 'rains' construction, Singlish allows for the expletive construction most probably inherited from English. 


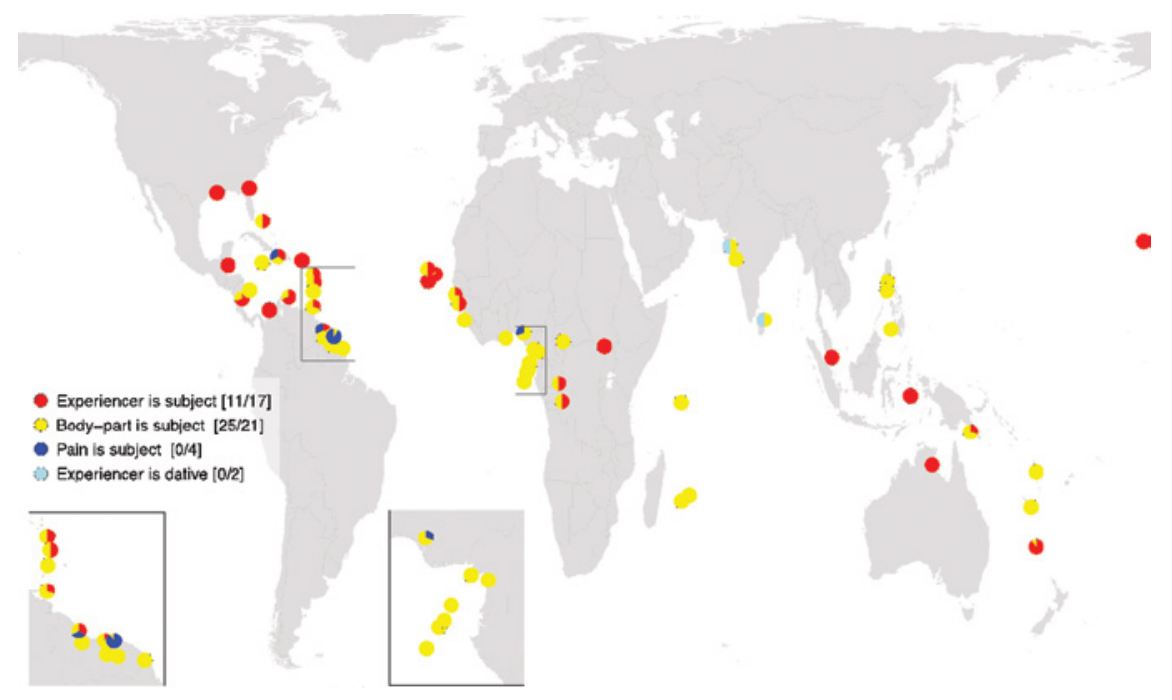

MAP 7 Experiencer constructions 'headache' in 59 creoles of APiCS (Michaelis and APiCS Consortium 2013b)

(26) Kriol (English-based; Schultze-Berndt and Angelo, 2013)

Maitbi im hedeik(...)

maybe 3SG headache [...]

'Maybe he has got a headache (...)'.

(27) Papiá Kristang (Portuguese-based; Baxter, 2013)

Yo teng due kabesa

1SG have hurt head

'I have a headache.'

In the second type, the body-part is coded as the subject of the sentence, as in 'Her head is aching' (yellow dots on Map 7). This type seems to be the most prominent construction in the APiCS sample. Within the creole languages showing this feature value, there are several subtypes. The experiencer can be retrievable via the oblique object of the verb 'eat', as in example (28) from Saramaccan, but it can also be expressed as a possessor of the body-part noun, as shown in example (29) from Angolar.

(28) Saramaccan (English-based; Aboh et al., 2013)

Edi ta njan a mi.

head ASP eat PREP 1 SG

'I have a headache.' (lit. 'The head is eating me.') 
(29) Angolar (Portuguese-based; Maurer, 2013a)

N'tê $m$ tha ruê.

head my PROG ache

'I have a headache.' (lit. 'My head is aching.')

Ghanaian Pidgin English shows a third subtype: the experiencer is expressed both through the possessive pronoun $m a$ and the object pronoun $m i$.

(30) Ghanaian Pidgin English (English-based; Huber, 2013)

$m a \grave{a} \quad h \varepsilon d$ dè pen/nak mi

1SG.POSS head PROG pain/knock 1SG.OBJ

'I have a headache.' (lit. 'My head is hurting/ knocking me.')

In yet another variant of the construction type 'body-part is subject', the experiencer is not expressed at all and has to be inferred from the linguistic or extra-linguistic context. One example comes from Diu Indo-Portuguese.

(31) Diu Indo-Portuguese (Portuguese-based; Cardoso, 2013)

Kabes ta $d w$-e.

head IPFV.NPST hurt-INF

'(My) head is hurting.'

The construction type corresponding to the next value is only marginally represented within the APiCS sample (dark blue dots on Map 7) and it exists only as an alternative option besides another construction. Here the 'pain' itself is coded as subject, as in 'Headache is affecting her'. An example comes from Sranan:

(32) Sranan (English-based; Winford and Plag, 2013)

Ede-hati e kiri mi.

head-hurt IPFV kill me

(lit.) 'A headache is killing me.'

In the last construction type (light blue dots on Map 7), the experiencer is marked as dative, that is, like the recipient of a typical ditransitive verb like 'give'. In the following example (33), the preposition $a$, which otherwise occurs on recipients, marks the human experiencer.

(33) Diu Indo-Portuguese (Portuguese-based; Cardoso, 2013)

A mi to siti dor do kabes.

DAT 1SG.OBL IPFV.NPST feel.INF pain of head

'I have a headache.' (lit. 'To me there is feeling a headache.') 
TABLE 3 Experiencer constructions with 'headache' (exclusive values only)

\section{APiCS creoles APiCS bi-clans of creoles}

\begin{tabular}{lrrrr}
\hline Experiencer is subject & 11 & $31 \%$ & 10 & $48 \%$ \\
Body-part is subject & 25 & $69 \%$ & 11 & $\mathbf{5 2 \%}$ \\
Total & 36 & $100 \%$ & 21 & $100 \%$
\end{tabular}

Note: 'Pain is subject' and 'Experiencer is dative' are not represented here because they are only shared options besides other construction types.

The 'experiencer is dative' construction occurs only marginally, too, but has a clear South Asian areal pattern (especially if one considers also other experiencer constructions as studied in $A P i C S$, e.g. experiencer constructions with 'like' and 'fear', see Michaelis and APiCS Consortium, 2013c; 2013d).

Table 3 summarizes the figures for the experiencer constructions. To keep the picture somewhat simple, again only languages with exclusive values are represented. The numbers for 'pain is subject' and 'experiencer is subject' constructions thus do not show up, as they are shared feature values and occur only as options besides other construction types (for a full picture see Michaelis and APiCS Consortium, 2013b).

Considering the figures in Table 3 for the APiCS creoles, one might be led to think that the 'body-part' construction is much more prominent across creoles than the 'experiencer is subject' construction as it is present in $69 \%$ of all creoles in APiCS. But in the bi-clan distribution, uniformly coded languages of the same bi-clan are counted only once (for instance, 7 Macro-Sudan/English creoles show the 'body-part' construction and count only once), and therefore there is a nearly equal split between the two construction types: $52 \%$ 'bodypart is subject' vs. $48 \%$ 'experiencer is subject'. Thus both constructions are well represented among creole languages.

What is the origin of the different construction types in the creoles? It is interesting to note that many APiCS creoles with English, Dutch, and French lexifiers only have body-part subjects (for instance, Ghanaian Pidgin English, Angolar, Nengee, Jamaican, Seychelles Creole, Tayo). This option is at best one possible construction in these European lexifiers, but it is certainly not the most prominent construction, as the most neutral way of referring to this experience is to express the experiencer in subject position, as in I have a headache, French J'ai mal à la tête [I.have pain at the head]. This leads me to suspect substrate influence also in this feature. Unfortunately, there is no WALS chapter on experiencer constructions, and the few systematic typological studies available focus on European languages (see Bossong, 1998; Haspelmath, 2001). 
For creoles with West African substrates, Ameka's (1990) description of experiencer constructions in Ewe (a Kwa language of West Africa) is of great interest. Ameka (1990:165) shows that the body-part subject in 'headache' situations is the only construction type available in this language.

(34) Ewe (Kwa; Ameka, 1990: 165)

ta vé kofi

head pain Kofi

'Kofi had a headache.' (lit. 'head pained Kofi')

Lefebvre (1998: 251) cites a structurally very similar example from Fongbe, a closely related language, where the body-part is subject, with the experiencer encoded as the object of the verb 'eat'.

(35) Fongbe (Lefebvre, 1998: 251)

Tà dŭ mi.

head eat me

'I have a headache.' (lit. 'head is eating me.')

In Swahili, a Bantu language, such experiences are also expressed by a construction where the body-part is subject:

(36) Swahili (Madan, 1902, s.v.)

kichwa ch-a-ni-uma

head 3SG.SBJ-PRS-1 OBJ.hurt

'I have a headache.' (lit. 'head is aching me.')

Thus, quite a few of the Atlantic and French-based Indian Ocean creoles showing the body-part pattern are most probably influenced by their substrates.

There is further good evidence that another construction type was calqued on a substrate/adstrate pattern: the 'experiencer is dative' construction, which is geographically restricted. The two creole languages with this pattern are both located in South Asia: Diu Indo-Portuguese (see example 33) and Sri Lanka Portuguese. ${ }^{18}$ If one looks at the relevant substrate/adstrate languages, one finds that the corresponding pattern of dative-marked experiencers is widespread in South Asian languages (see examples 37, 38). At the same time such a construction is not very common in the world's languages, and moreover not present in the corresponding lexifier language Portuguese, where

18 A third language in APiCS with this feature value is the mixed language Sri Lankan Malay (cf. Slomanson, 2013). 
the experiencer is coded as subject (cf. Tenh-o dor de cabeça [have.1SG pain of head]). In the literature this construction is often called "dative subject construction" (see also Michaelis and APiCS Consortium, 2013c on experiencer constructions with like').

(37) Gujarati (Indo-Aryan; Cardona, 1965: 110)

mohne daNtmaN dukhe che

1SG.DAT tooth be.painful AUX

'I have a toothache.' (lit. 'To me the tooth is painful.')

(38) Malayalam (Nizar, 2010)

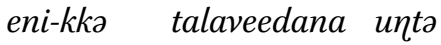

1SG-DAT headache be.PRS

'I have a headache.' (lit. 'To me is a headache.')

The marking of experiencers in the South Asian APiCS languages by this kind of dative case or adposition can thus clearly be traced back to their substrates/ adstrates.

What about the 'experiencer is subject' construction which is well represented in the creoles in APiCS? Should we attribute all cases of this feature value in creoles to their (Western European) lexifiers? It may well be that in some of the more acrolectal French-/English-based creoles with this construction, such as Louisiana Creole or Gullah, this interpretation is valid.

But for languages such as Kriol and Papiá Kristang (see examples 26-27), the situation is different. One of Kriol's adstrate languages is Jaminjung, a language of Northern Australia. In this language, it is also the experiencer which is coded as subject in constructions with headache (Schultze-Berndt, p.c.). So the lexifier English (I have a headache) and Jaminjung show the same pattern. The situation is similar for Papiá Kristang, whose most important substrate/ adstrate language is colloquial Malay of Malacca. According to David Gil (p.c.), the headache experience can be expressed as in (39) in colloquial Malay:

(39) Colloquial Malay (Gil, p.c.)

Aku ada sakit kepala
1SG exist/have hurt head
'I have a headache.'

The predicate $a d a$ is used in existential constructions, but also in predicative possessive constructions. So it may well be that this colloquial Malay construction is the source of the 'experiencer is subject' construction in Papiá Kristang 
(see example 27). It so happens that Portuguese has a very similar construction with Tenho dor de cabeça 'I have pain of head'.

Generalizing over cases like Kriol and Papiá Kristang, it becomes clear that the creole patterns ultimately mirror substrate/adstrate patterns which themselves may happen to coincide with the lexifier ones (see the same line of argumentation for cases of indirect-object marking cited in Section 3). The languages showing 'experiencer is subject' pattern are therefore consistent with the present claim that in 'headache' constructions, too, it is the substrate/ adstrate pattern which overwhelmingly prevails in creoles world-wide.

\section{Motion-To and Motion-From Constructions}

The last construction type to be discussed are motion-to and motion-from constructions. Here the question is whether creole languages use the same strategy or different strategies to express the two opposite orientations: (i) motion to a reference object (GOAL, 'I go to the market'), and (ii) motion from a reference object (SOURCE, 'I come from the market'). The reference objects in these constructions are frequent places like 'home', 'town', 'village', 'market', or 'forest' (cf. the corresponding APiCS chapter Michaelis and APiCS Consortium, 2013e).

All Western European lexifier languages have different constructions for motion-to and motion-from, using different prepositions: English to town/ from town, French à la maison/de la maison, Portuguese ao mercado/do mercado. But in APiCS, it is striking to see that many European-based creoles do not follow the Western European lexifier patterns and instead mark goal and source identically, as illustrated in examples (40a-b) from Seychelles Creole and (41a-b) from Krio. ${ }^{19}$

(40) Seychelles Creole (French-based; Michaelis and Rosalie, 2013)

a. motion-to: mon al dan bwa

1SG go in forest

'I go into the forest.'

$\begin{array}{ll}\text { b. motion-from: } & \text { mon sorti dan bwa } \\ & \text { 1SG come.from in forest } \\ & \text { 'I come out of the forest.' }\end{array}$

19 Throughout this section, the (a) examples show motion-to constructions and the (b) examples show motion-from constructions. 
(41) Krio (English-based; Finney, 2013)
a. motion-to:
a di go
1 SG PROG go LOC ART market
'I am going to the market.'
$\begin{array}{rllllll}\text { b. motion-from: } & A \quad \text { jes } & \text { komst } & \text { na } & \text { di } & \text { makit } \\ & \text { 1SG just come } & \text { LOC ART } & \text { market } \\ & \text { 'I just came back from the market.' }\end{array}$

It is not the case that the creoles cited do not use any prepositions, but the interesting fact is that they use the same preposition to refer to both opposite orientations. Apparently, the prepositions refer to something else than the prepositions to, from, $\grave{a}$ and $d e$ in the lexifier languages. To better understand the differences between Seychelles Creole and its lexifier French, and Krio and its lexifier English, I would like to refer to Figure 1, where a local situation is decomposed.

A moving or located object ('I') is involved in a situation ('go') which is oriented ('to') with respect to a local region ('in') of a reference object ('forest'). In English, the two semantic components 'oriented with respect to' (РATH) and 'local region of' (PLACE) are fused into one preposition into (which shows a somewhat unexpected linearization, first PLACE in-and then PATH -to). Within the PATH segment, the motion-to and motion-from concepts are marked differently, into vs. out of. The same is true for French: motion-to is marked by the preposition $\grave{a}$, whereas motion-from is marked by the preposition $d e$.

\section{English}

a. motion-to I go into the forest.

b. motion-from

I come from/out of the forest. Je sors de la forêt.

French

Je vais dans la forêt

If one now compares the corresponding examples from Seychelles Creole and Krio to the English and French ones, it becomes obvious that in the creole languages the prepositions dan and $n a$ do not refer to path, but to place or

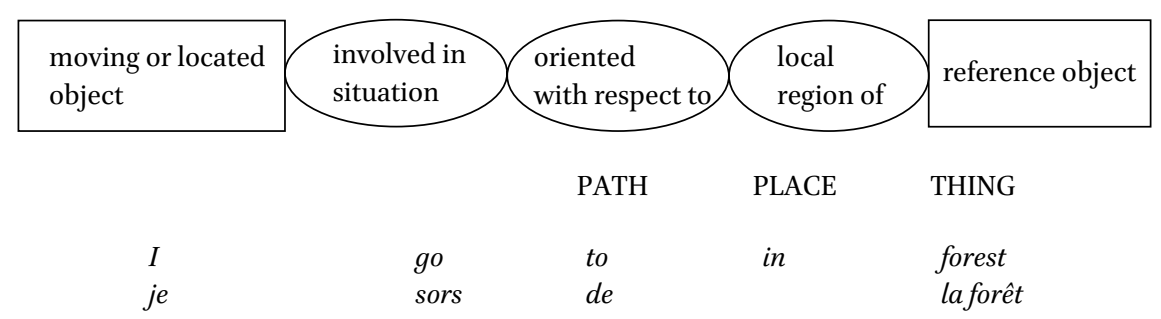

FIGURE 1 Structure of a local situation (Lehmann 1992: 629; Jackendoff 1983: 161ff.) 


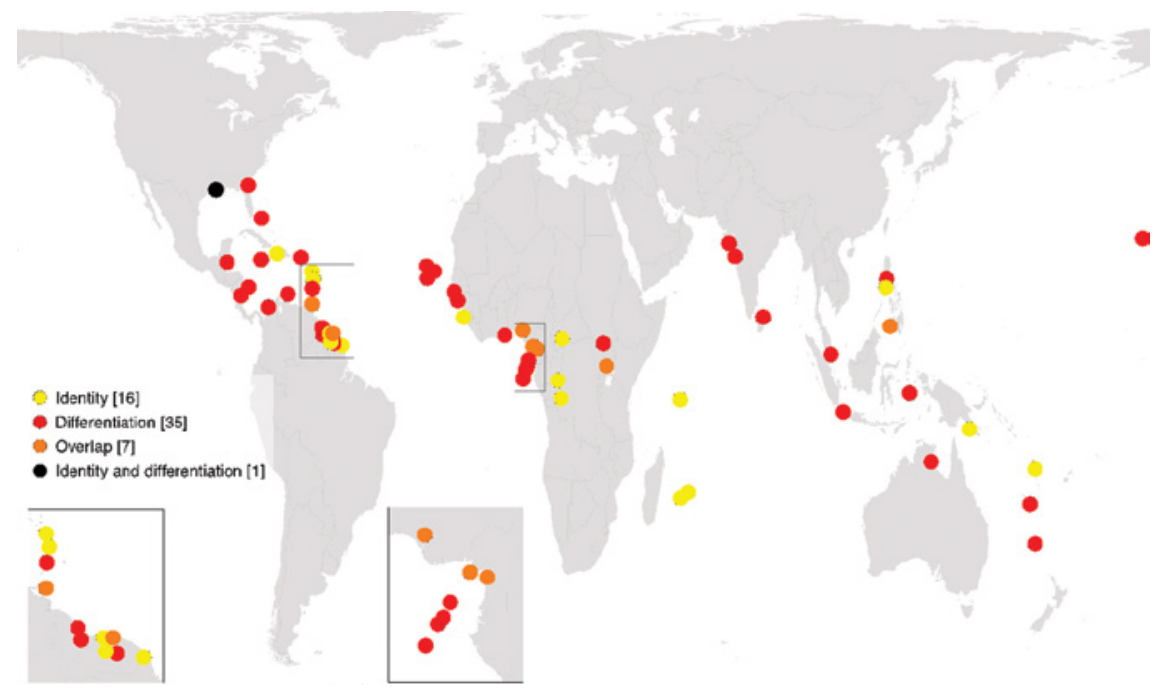

MAP 8 Motion-to/motion-from in 59 creoles of APiCS (Michaelis and APiCS Consortium 2013e)

local region of the reference object, the 'forest' or the 'market' in our examples. Thus, these prepositions are the same in both orientations as they are not involved in the expression of path (see also Wälchli and Zúñiga, 2006: 292 for Haitian Creole, where we find similar examples). It is from the meaning of the verbs go and come that the hearer has to infer the relevant orientation.

As illustrated in Map 8, 16 creoles code motion-to and motion-from constructions identically (yellow dots).

35 creoles in APiCS code motion-to and motion-from differently (red dots on Map 8). This can be achieved through three coding subtypes. First, a language has two different prepositions to mark motion-to and motion-from, as also seen in the European lexifiers cited above. This is the case, for instance, in Bahamian Creole, Palenquero, and Batavia Creole.

(43) Batavia Creole (Portuguese-based; Maurer, 2013b)
a. Ile anda nu chang $[\ldots]$.
he go to land

'He went to the property [...].'

b. Di undi sta bi? - Di otër tera.

from where IPFV come - from other country

'Where do you come from? - From abroad.'

The second subtype of this feature value consists of an optional adposition to express motion-to, but a different obligatory adposition to express 
motion-from. Here we find languages like Creolese, Papiamentu, two Cape Verdean Creole varieties, Kriol, and Sri Lanka Portuguese.

In a third subtype of the value "differentiation", motion-to is never marked, whereas motion-from is always marked by an adposition or a serial verb. Jamaican, Casamancese Creole, Guinea-Bissau Kriyol, Papiá Kristang, and Tayo have prepositions ( frahn, di, de) for expressing motion-from (see example 44). Sri Lanka Portuguese shows postpositions, and the Gulf of Guinea creoles (Angolar, Principense, Santome, and Fa d'Ambô) mark motion-from with the serial verb fô/fo 'come from' (see example 45).

(44) Casamancese Creole (Portuguese-based; Biagui and Quint, 2013)

a. Mariya bay fera.

Mary go market

'Mary went to the market.'

b. Mariya bey di fera.

Mary come from market

'Mary came back from the market.'

(45) Principense (Portuguese-based; Maurer 2013c)

a. $N$ we fya.

1SG go market

'I went to the market.'

b. $N$ vika fo fya.

1SG come come.from market

'I came from the market.'

In seven languages there is overlap in the coding of motion-to and motionfrom constructions (orange dots on Map 8). In Cameroon Pidgin English (Schröder, 2013), for instance, the preposition $f_{0}$ 'in, at, on, to, from' can be used in both orientation contexts, whereas motion-to can additionally be expressed without any marker.

As Table 4 illustrates, 16 creole languages mark motion-to and motion-from identically. On top of that, there are 7 more creole languages that show overlap, i.e. they may have identical marking of motion-to and motion-from (besides differentiation, as in Cameroon Pidgin English, mentioned above). I subsume these languages under the group of identity marking because, given that all Western European lexifiers show the differentiation pattern, the possibility to 
TABLE $4 \quad$ Motion-to and motion-from in creoles (exclusive values only) ${ }^{20}$

\begin{tabular}{lrrrc}
\hline & \multicolumn{2}{c}{ APiCS creoles } & \multicolumn{2}{c}{ APiCS bi-clans of creoles } \\
\hline Identity & 16 & $28 \%$ & 7 & $\mathbf{2 8 \%}$ \\
Differentiation & 35 & $60 \%$ & 14 & $\mathbf{5 6 \%}$ \\
Overlap & 7 & $12 \%$ & 4 & $\mathbf{1 6 \%}$ \\
Total & 58 & $100 \%$ & 25 & $\mathbf{1 0 0 \%}$ \\
& & & & \\
\hline
\end{tabular}

mark both orientations identically is remarkable and is in need of being explained. If we consider the bi-clan distribution and add the bi-clans showing overlap ( $16 \%)$ to the ones showing identity $(28 \%)$, we end up with a total of $44 \%$ bi-clans that may show the identity pattern.

Interestingly, we observe a split between English- and French-based Atlantic/ Indian Ocean creoles: All French-based creoles show the identity pattern, whereas the English-based Atlantic creoles mostly show differentiation. It is only the English-based Surinamese creoles ((Early) Sranan and Saramaccan), Trinidad English Creole, and the West African English-based languages which show identical coding or overlap. Other Caribbean English-based creoles, such as Jamaican, Creolese, Belizean Creole, and Gullah, follow the English differentiation pattern.

How can we explain the identity pattern which is not available in the European lexifier languages? Even though there is no WALS map for this feature, we have good cross-linguistic data on intransitive motion-to/motion-from constructions (Wälchli and Zuñiga, 2006). First, in many West African and Bantu languages, which are substrates of the Atlantic and Indian Ocean contact languages, motion-to and motion-from in sentences relating to a situation like 'I go to/come from the market' are not overtly marked, but orientation is expressed through the semantics of the verb (see Michaelis, 2008; Wälchli and Zúñiga, 2006: 292ff.). If prepositions are used, they do not refer to orientation (motion-to/motion-from), but to the local region of the located object (see Fig. 1). This pattern can be found in a great variety of Niger-Congo languages, such as Ewe, Twi, Efik, Bambara, Zulu, Swahili. In Swahili, the postnominal locative case marker $-n i$ indicates the local region of the reference object and not path. Thus, -ni closely mirrors the prepositions in the creole examples (40-41).

20 One minor value ("identity and differentiation") has been omitted (for the full picture, see Michaelis and APiCS Consortium, 2013e). 
(46) Swahili (New Testament, Mark 1, 11; 19)

a. a-ka-enda bahari-ni 3SG-SEQ-go sea-LOC.in

'He went to the sea'.

\begin{tabular}{|c|c|c|}
\hline b. sauti & $i-k a-t o k a$ & mbingu-ni \\
\hline
\end{tabular}

Second, in Philippinic languages, e.g. Tagalog, which are substrate/adstrates to the Chabacano varieties, goal and source may not be overtly marked either, as is the case in Ternate Chabacano and Zamboango Chabacano (whereas Cavite Chabacano variety has different markers for goal and source).${ }^{21}$

However, there are more than $50 \%$ of the creole bi-clans that differentiate between motion-to and motion-from. Do these languages follow their Western European lexifier patterns? Here I will argue again that the picture is more complex. If we have a closer look at the relevant contact situations, we see that in the overwhelming number of cases, the relevant substrate/adstrate languages also have different means to express motion-to and motion-from. Tayo, for instance, has Oceanic substrates which differentiate motion-to and motion-from prepositions (Rivierre, 1980: 220, 351; Osumi, 1995: 80-81; Bril, 2002: 296, 309). The same holds for English-based Kriol, which has differentiating substrates/ adstrates (e.g. Nunggubuyu, cf. Wälchli and Zuñiga, 2006: 300). One important substrate of Papiá Kristang and Batavia Creole, Malay, has different goal/ source marking, too. Korlai, Diu Indo-Portuguese and Sri Lanka Portuguese all have differentiating adstrate languages. In all these cases, it could be argued that the creole languages just continue the pattern of their French, Portuguese or English lexifiers, which differentiate both orientations. But as already noted for previous construction types, I would argue again that these examples are consistent with my claim that it is the substrate/adstrate pattern that prevails over the lexifier pattern. If it happens that both lexifier and substrate have the same typological feature value, no positive evidence can be adduced. However, these cases do not invalidate the overall generalization that also motion-to/ motion-from constructions mirror the substrate patterns instead of the lexifier patterns of the creoles.

21 It is not clear to me why so many English-based Atlantic creoles with West-African substrates do not show the identity pattern. Interestingly, the English-based Surinamese creoles reflect the substratal identity pattern. It is not only in this feature that we see this different behavior in the English-based Atlantic creoles (for a similar picture see the 
In this paper, I have shown that in the domain of valency, creoles show a substantial amount of constructional calquing from their substrates. In all four construction types (ditransitive constructions (Section 3 ), weather constructions (Section 4), experiencer constructions (Section 5), and motion constructions (Section 6)), I was able to demonstrate recurrent matches between substrate and creole structures (contrasting with lexifier structures) in different regions of the world and with different substrates. Such a rich picture, which became possible with the publication of the Atlas of Pidgin and Creole Language Structures, excludes the possibility of an accident and makes substrate influence the key in explaining the creole data.

For some construction types, substrate and lexifier patterns may happen to be very similar or identical to the creole pattern. This is for instance the case in the indirect-object construction in Tayo, where French and Oceanic languages both happen to have the indirect construction, or the experiencer is subject' constructions in Kriol and Papiá Kristang, where again English and Portuguese on the one hand and Northern Australian languages and Colloquial Malay on the other hand happen to feature very similar 'experiencer is subject' constructions. Indeed, in these cases we do not have positive evidence for substrate or adstrate influence, and thus one could argue in favor of lexifier continuity or reinforcement of similar substrate and lexifier patterns. Such a line of argumentation is plausible if one only looks at isolated cases of creoles with their contributing languages. But as soon as we adopt a systematic global comparative perspective, these apparent counterexamples tie in nicely with the overall claim put forward in this paper. With respect to the four valency patterns discussed here, it is the substrate pattern that prevails in creolization. The two alternative claims are not borne out by the APiCS data, namely that (i) the overwhelming number of creoles mirror their lexifier patterns or (ii) that creoles only continue substrate patterns if they are reinforced by a similar lexifier pattern.

These findings strongly support the idea that during the process of creolization the creators of creoles systematically calqued the valency patterns of their dominant languages (substrates) onto the emerging creoles.

I am very much aware of the fact that the present paper is only the first step in a much more ambitious endeavour, namely to undertake a large-scale meticulous qualitative world-wide comparison of creoles with their contributing

APiCS feature "noun phrase conjunction and comitative", http://apics-online.info/param eters/71\#2/13.9/10.2). More research is needed here. 
languages against the background of the world-wide diversity of languages. Such a comparison will tell us then which structural features are prone to be calqued during creolization and which are not, for instance, creole word order patterns seem to mirror their lexifier patterns more faithfully (cf. Lefebvre, 2015; Michaelis and Haspelmath, 2014; Velupillai, 2015). ${ }^{22}$

\section{Acknowledgements}

I am grateful to Martin Haspelmath and three anonymous reviewers for their comments on an earlier version of this paper. Furthermore, the support of the European Research Council (ERC Advanced Grant 670985, Grammatical Universals) is gratefully acknowledged.

\section{References}

Aboh, Enoch O., Tonjes Veenstra, and Smith S.H. Norval. 2013. Saramaccan structure dataset. In Susanne Maria Michaelis, Philippe Maurer, Martin Haspelmath, and Magnus Huber (eds.), Atlas of Pidgin and Creole Language Structures Online. Leipzig: Max Planck Institute for Evolutionary Anthropology. http://apics-online .info/ (accessed June 7, 2016).

Alleyne, Mervyn C. 1980. Comparative Afro-American - An Historical-Comparative Study of English-Based Afro-American Dialects. Ann Arbor: Karoma.

Ameka, Felix. 1990. The grammatical packaging of experiencers in Ewe: A study in the semantics of syntax. Australian Journal of Linguistics 10:139-181.

Baker, Philip and Sibylle Kriegel. 2013. Mauritian Creole dataset. In Susanne Maria Michaelis, Philippe Maurer, Martin Haspelmath, and Magnus Huber (eds.), Atlas of Pidgin and Creole Language Structures Online. Leipzig: Max Planck Institute for Evolutionary Anthropology. http://apics-online.info/ (accessed June 7, 2016).

Bakker, Peter. 2008. Pidgins versus creoles and pidgincreoles. In Silvia Kouwenberg and John Victor Singler (eds.), Handbook of Pidgin and Creole Studies, 130-157. Oxford: Wiley-Blackwell.

Bakker, Peter, Aymeric Daval-Markussen, Mikael Parkvall, and Ingo Plag. 2011. Creoles are typologically distinct from non-creoles. Journal of Pidgin and Creole Languages $26(1): 5-42$.

22 See Muysken and Smith (2015) for a very detailed picture of which of the creole features of English-based Surinamese creoles were calqued from their West African substrate languages Gbe and Kikongo and which were apparently not calqued. 
Baxter, Alan. 2013. Papiá Kristang structure dataset. In Susanne Maria Michaelis, Philippe Maurer, Martin Haspelmath, and Magnus Huber (eds.), Atlas of Pidgin and Creole Language Structures Online. Leipzig: Max Planck Institute for Evolutionary Anthropology. http://apics-online.info/ (accessed June 7, 2016).

Biagui, Noël Bernard and Nicolas Quint. 2013. Casamancese Creole structure dataset. In Susanne Maria Michaelis, Philippe Maurer, Martin Haspelmath, and Magnus Huber (eds.), APiCS Online. Leipzig: Max Planck Institute for Evolutionary Anthropology. http://apics-online.info/ (accessed June 7, 2016).

Bickerton, Derek. 1981. Roots of Language. Ann Arbor: Karoma.

Boretzky, Norbert. 1983. Kreolsprachen, Substrate und Sprachwandel. Wiesbaden: Harrassowitz.

Bossong, Georg. 1998. Le marquage de l'expérient dans les langues d'Europe. In Jack Feuillet (ed.). Actance et valence dans les langues d'Europe, 259-94. Berlin: Mouton de Gryuter.

Bril, Isabelle. 2002. Le nêlêmwa (Nouvelle-Calédonie): Analyse syntaxique et sémantique. Paris: Peeters.

Cardona, George. 1965. A Gujarati Reference Grammar. Philadelphia: University of Pennsylvania Press.

Cardoso, Hugo C. 2013. Diu Indo-Portuguese structure dataset. In Susanne Maria Michaelis, Philippe Maurer, Martin Haspelmath, and Magnus Huber (eds.), Atlas of Pidgin and Creole Language Structures Online. Leipzig: Max Planck Institute for Evolutionary Anthropology. http://apics-online.info/ (accessed June 7, 2016).

Chaudenson, Robert. 1992. Des îles, des hommes, des langues. Paris: L'Harmattan.

Conners, Thomas J. and David Gil. 2013. Jakarta Indonesian valency patterns. In Iren Hartmann, Martin Haspelmath, and Bradley Taylor (eds.), Valency Patterns Leipzig. Leipzig: Max Planck Institute for Evolutionary Anthropology. Available online at http://valpal.info/languages/jakarta-indonesian/examples/19 (accessed September 21, 2015).

Creissels, Denis. 2005. A typology of subject and object markers. In Erhard F.K. Voeltz (ed.), Studies in African Linguistic Typology, 43-70. Amsterdam / Philadelphia: John Benjamins.

Daval-Markussen, Aymeric. 2014. First steps towards a typological profile of creoles. Acta Linguistica Hafniensia 45(2):1-22.

Dryer, Matthew and Martin Haspelmath (eds.). 2013. The World Atlas of Language Structures Online. Leipzig: Max Planck Institute for Evolutionary Anthropology. http://wals.info (accessed September 21, 2015).

Ehrhart, Sabine and Melanie Revis. 2013. Tayo structure dataset. In Susanne Maria Michaelis, Philippe Maurer, Martin Haspelmath, and Magnus Huber (eds.), Atlas of Pidgin and Creole Language Structures Online. Leipzig: Max Planck Institute for Evolutionary Anthropology. http://apics-online.info/ (accessed June 7, 2016). 
Eriksen, Pål, Seppo Kittilä, and Leena Kolehmainen. 2010. The linguistics of weather: cross-linguistic patterns of meteorological expressions. Studies in Language 34(3):565-601.

Eriksen, Pål, Seppo Kittilä, and Leena Kolehmainen. 2012. Weather and language. Language and Linguistics Compass 6(6):383-402.

Fattier, Dominique. 2013. Haitian Creole structure dataset. In Susanne Maria Michaelis, Philippe Maurer, Martin Haspelmath, and Magnus Huber (eds.), Atlas of Pidgin and Creole Language Structures Online. Leipzig: Max Planck Institute for Evolutionary Anthropology. http://apics-online.info/ (accessed June 7, 2016).

Finney, Malcolm Awadajin. 2013. Krio structure dataset. In Susanne Maria Michaelis, Philippe Maurer, Martin Haspelmath, and Magnus Huber (eds.), Atlas of Pidgin and Creole Language Structures Online. Leipzig: Max Planck Institute for Evolutionary Anthropology. http://apics-online.info/ (accessed June 7, 2016).

François, Alexandre. 2001. Contraintes de structures et liberté dans l'organisation du discours. Une description du mwotlap, langue océanienne du Vanuatu. $\mathrm{PhD}$ thesis Université Paris-IV Sorbonne.

Güldemann, Tom. 2010. Sprachraum and geography: Linguistic macro-areas in Africa. In Alfred Lameli, Roland Kehrein, and Stefan Rabanus (eds.), Language and Space: An International Handbook of Linguistic Variation, vol. 2: Language mapping, 561-585, Maps 2901-2914. Berlin: De Gruyter Mouton.

Hagemeijer, Tjerk. 2013. Santome structure dataset. In Susanne Maria Michaelis, Philippe Maurer, Martin Haspelmath, and Magnus Huber (eds.), Atlas of Pidgin and Creole Language Structures Online. Leipzig: Max Planck Institute for Evolutionary Anthropology. http://apics-online.info/ (accessed June 7, 2016).

Haspelmath, Martin. 2001. Non-canonical marking of core arguments in European languages. In Alexandra Y. Aikhenvald, Robert M.W. Dixon, and Masayuki Onishi (eds). Non-canonical Marking of Subjects and Objects, 53-83. Amsterdam / Philadelphia: John Benjamins.

Haspelmath, Martin. 2013. Ditransitive constructions: the verb 'give'. In Matthey Dryer and Martin Haspelmath (eds.). The World Atlas of Language Structures Online. Leipzig: Max Planck Institute for Evolutionary Anthropology. http://wals.info/ chapter/105 (accessed June 7, 2016).

Haspelmath, Martin, Susanne Maria Michaelis, and the APiCS Consortium. 2013. Ditransitive constructions with 'give'. In Susanne Maria Michaelis, Philippe Maurer, Martin Haspelmath, and Magnus Huber (eds.). The Atlas of Pidgin and Creole Language Structures, 236-239. Oxford: Oxford University Press.

Haspelmath, Martin and Susanne Maria Michaelis. 2014. Hybridization, social conditions and word order. Paper presented at the workshop "Grammatical hybridization and social conditions”, MPI-EVA Leipzig 16-18 October 2014. 
Huber, Magnus. 1999. Ghanaian Pidgin English in its West African Context: A Sociohistorical and Structural Analysis. Amsterdam: John Benjamins.

Huber, Magnus. 2013. Ghanaian Pidgin English structure dataset. In Susanne Maria Michaelis, Philippe Maurer, Martin Haspelmath, and Magnus Huber (eds.), Atlas of Pidgin and Creole Language Structures Online. Leipzig: Max Planck Institute for Evolutionary Anthropology. http://apics-online.info/ (accessed June 7, 2016).

Holm, John A. 1988. Pidgins and Creoles. Volume 1: Theory and Structure. Cambridge: Cambridge University Press.

Holm, John A. and Peter L. Patrick. 2007. Comparative Creole Syntax: Parallel Outlines of 18 Creole Grammars. London: Battlebridge.

Intumbo, Incanha, John A. Holm, and Liliana Inverno. 2013. Guinea-Bissau Kriyol structure dataset. In Susanne Maria Michaelis, Philippe Maurer, Martin Haspelmath, and Magnus Huber (eds.), Atlas of Pidgin and Creole Language Structures Online. Leipzig: Max Planck Institute for Evolutionary Anthropology. http://apics-online .info/ (accessed June 7, 2016).

Jackendoff, Ray. 1983. Semantics and Cognition, Cambridge, Massachusetts: MIT press. Keesing, Roger M. 1985. Kwaio Grammar. Canberra: Australian National University.

Kofod, Frances. 1978. The Miriwung Language. A Phonological and Morphological Study. MA thesis. University of New England.

Kortmann, Bernd and Kerstin Lunkenheimer (eds.). 2013. Electronic World Atlas of Varieties of English (eWAVE). Leipzig: Max Planck Institute for Evolutionary Anthropology. http://ewave-atlas.org/.

Koopman, Hilda. 1986. The genesis of Haitian. In Pieter Muysken and Norval Smith (eds.). Substrata versus Universals in Creole Genesis, 231-258. Amsterdam: John Benjamins.

Kouwenberg, Silvia. 2013. Papiamentu structure dataset. In Susanne Maria Michaelis, Philippe Maurer, Martin Haspelmath, and Magnus Huber (eds.), Atlas of Pidgin and Creole Language Structures Online. Leipzig: Max Planck Institute for Evolutionary Anthropology. http://apics-online.info/ (accessed June 7, 2016).

Kroeger, Paul. 1993. Phrase Structure and Grammatical Relations in Tagalog. Leland Stanford Junior University.

Lefebvre, Claire. 1998. Creole Genesis and the Acquisition of Grammar. Cambridge: Cambridge University Press.

Lefebvre, Claire. 2015. Functional Categories in Three Atlantic Creoles: Saramaccan, Haitian and Papiamentu. Amsterdam / Philadelphia: John Benjamins.

Lefebvre, Claire (ed.). 2011. Creoles, their Substrates, and Language Typology. Amsterdam / Philadelphia:John Benjamins.

Lefebvre, Claire and Anne-Marie Brousseau. 2002. A Grammar of Fongbe. Berlin: Mouton de Gruyter. 
Lehmann, Christian. 1992. Yukatekische lokale Relatoren in typologischer Sicht. Zeitschrift für Phonetik, Sprachwissenschaft und Kommunikationsforschung (ZPSK), 45: 626-641.

Lim, Lisa and Umberto Ansaldo. 2013. Singlish structure dataset. In Susanne Maria Michaelis, Philippe Maurer, Martin Haspelmath, and Magnus Huber (eds.), Atlas of Pidgin and Creole Language Structures Online. Leipzig: Max Planck Institute for Evolutionary Anthropology. http://apics-online.info/ (accessed June 7, 2016).

Madan, Arthur Cornwallis. 1902. English-Swahili Dictionary. $2^{\text {nd }}$ edition. Oxford: Clarendon Press.

Maurer, Philippe. 2013a. Angolar structure dataset. In Susanne Maria Michaelis, Philippe Maurer, Martin Haspelmath, and Magnus Huber (eds.), Atlas of Pidgin and Creole Language Structures Online. Leipzig: Max Planck Institute for Evolutionary Anthropology. http://apics-online.info/ (accessed June 7, 2016).

Maurer, Philippe. 2013b. Batavia Creole structure dataset. In Susanne Maria Michaelis, Philippe Maurer, Martin Haspelmath, and Magnus Huber (eds.), Atlas of Pidgin and Creole Language Structures Online. Leipzig: Max Planck Institute for Evolutionary Anthropology. http://apics-online.info/ (accessed June 7, 2016).

Maurer, Philippe. 2013c. Principense structure dataset. In Susanne Maria Michaelis, Philippe Maurer, Martin Haspelmath, and Magnus Huber (eds.), Atlas of Pidgin and Creole Language Structures Online. Leipzig: Max Planck Institute for Evolutionary Anthropology. http://apics-online.info/ (accessed June 7, 2016).

McWhorter, John H. 1997. Towards a New odel of Creole Genesis. New York: Peter Lang.

Michaelis, Susanne. 2008. Valency patterns in Seychelles Creole: Where do they come from? In Susanne Michaelis (ed.). Roots of Creole Structures: Weighing the Contribution of Substrates and Superstrates, 225-251. Amsterdam / Philadelphia: John Benjamins.

Michaelis, Susanne Maria. 2017. Avoiding bias in comparative creole studies: Stratification by lexifier and substrate. DoI: 10.5281/zenodo.1255790.

Michaelis, Susanne Maria and the APiCS Consortium. 2013a. Raining constructions. In Susanne Maria Michaelis, Philippe Maurer, Martin Haspelmath, and Magnus Huber (eds.). The Atlas of Pidgin and Creole Language Structures, 256-259. Oxford: Oxford University Press.

Michaelis, Susanne Maria and the APiCS Consortium. 2013b. Experiencer constructions with 'headache'. In Susanne Maria Michaelis, Philippe Maurer, Martin Haspelmath, and Magnus Huber (eds.). The Atlas of Pidgin and Creole Language Structures, 260-263. Oxford: Oxford University Press.

Michaelis, Susanne Maria and the APiCS Consortium 2013c. Experiencer constructions with 'like'. In Susanne Maria Michaelis, Philippe Maurer, Martin Haspelmath, and Magnus Huber (eds.). The Atlas of Pidgin and Creole Language Structures, 264-267. Oxford: Oxford University Press. 
Michaelis, Susanne Maria and the APiCS Consortium 2013d. Experiencer constructions with 'fear. In Susanne Maria Michaelis, Philippe Maurer, Martin Haspelmath, and Magnus Huber (eds.). The Atlas of Pidgin and Creole Language Structures, 268271. Oxford: Oxford University Press.

Michaelis, Susanne Maria and the APiCS Consortium 2013e. Motion-to and motionfrom. In Susanne Maria Michaelis, Philippe Maurer, Martin Haspelmath, and Magnus Huber (eds.). The Atlas of Pidgin and Creole Language Structures, 322-325. Oxford: Oxford University Press.

Michaelis, Susanne Maria and Marcel Rosalie. 2013. Seychelles Creole structure dataset. In Susanne Maria Michaelis, Philippe Maurer, Martin Haspelmath, and Magnus Huber (eds.), Atlas of Pidgin and Creole Language Structures Online. Leipzig: Max Planck Institute for Evolutionary Anthropology. http://apics-online.info/ (accessed June 7,2016$)$.

Michaelis, Susanne Maria, Philippe Maurer, Martin Haspelmath, and Magnus Huber (eds.) 2013a. The Atlas of Pidgin and Creole Language Structures. Oxford: Oxford University Press.

Michaelis, Susanne Maria, Philippe Maurer, Martin Haspelmath, and Magnus Huber (eds.) 2013b. The Survey of Pidgin and Creole Language, 3 volumes, Oxford: Oxford University Press.

Michaelis, Susanne and Martin Haspelmath. 2003. Ditransitive constructions: Creole languages in a cross-linguistic perspective. Creolica (www.creolica.net).

Moyse-Faurie, Claire. 2013. Xârâcùù Valency Patterns. In Iren Hartmann, Martin Haspelmath, and Bradley Taylor (eds.), Valency Patterns Leipzig. Leipzig: Max Planck Institute for Evolutionary Anthropology. (Available online at http://valpal .info/languages/xaracuu (accessed September 21, 2015).

Mufwene, Salikoko S. 2001. The Ecology of Language Evolution. Cambridge: Cambridge University Press.

Muysken, Pieter and Norval Smith (eds.). 1986. Substrata versus Universals in Creole Genesis, Amsterdam: John Benjamins.

Muysken, Pieter and Norval Smith (eds.). 2015. Surviving the Middle Passage: The West Africa-Surinam Sprachbund. Berlin: De Gruyter Mouton.

Neumann-Holzschuh, Ingrid and Thomas A. Klingler. 2013. Louisiana Creole structure dataset. In Susanne Maria Michaelis, Philippe Maurer, Martin Haspelmath, and Magnus Huber (eds.), Atlas of Pidgin and Creole Language Structures Online. Leipzig: Max Planck Institute for Evolutionary Anthropology. http://apics-online .info/ (accessed June 7, 2016).

Nizar, Milla. 2010. Dative Subject Constructions in South-Dravidian Languages. $\mathrm{PhD}$ thesis Berkeley.

Osumi, Midori. 1995. Tinrin Grammar. Honolulu: University of Hawai'i Press.

Paauw, Scott. 2013. Ambon Malay structure dataset. In Susanne Maria Michaelis, Philippe Maurer, Martin Haspelmath, and Magnus Huber (eds.), Atlas of Pidgin and 
Creole Language Structures Online. Leipzig: Max Planck Institute for Evolutionary Anthropology. http://apics-online.info/ (accessed June 7, 2016).

Parkvall, Mikael. 2000. Out of Africa: African Influences in Atlantic Creoles. London: Battlebridge.

Parkvall, Mikael. 2008. The simplicity of creoles in a cross-linguistic perspective. In Matti Miestamo, Kaius Sinnemäki and Fred Karlsson (eds.), Language Complexity: Typology, Contact, Change, 265-285. Amsterdam / Philadelphia: John Benjamins.

Rivierre, Jean-Claude. 1980. La Langue de Touho: Phonologie et grammaire du Cèmūhî (Nouvelle Calédonie). Paris: Peeters.

Schröder, Anne. 2013. Cameroon Pidgin English. In Susanne Maria Michaelis, Philippe Maurer, Martin Haspelmath, and Magnus Huber (eds.), Atlas of Pidgin and Creole Language Structures Online. Leipzig: Max Planck Institute for Evolutionary Anthropology. http://apics-online.info/ (accessed June 7, 2016).

Schultze-Berndt, Eva 2013. Jaminjung valency patterns. In Iren Hartmann, Martin Haspelmath, and Bradley Taylor (eds.). Valency Patterns Leipzig. Leipzig: Max Planck Institute for Evolutionary Anthropology. (Available online at http://valpal .info/languages/jaminjung/examples/33 (accessed September 21, 2015).

Schultze-Berndt, Eva and Denise Angelo. 2013. Kriol structure dataset. In Susanne Maria Michaelis, Philippe Maurer, Martin Haspelmath, and Magnus Huber (eds.), Atlas of Pidgin and Creole Language Structures Online. Leipzig: Max Planck Institute for Evolutionary Anthropology. http://apics-online.info/ (accessed June 7, 2016).

Siegel, Jeff. 1999. Transfer constraints and substrate influence in Melanesian Pidgin. Journal of Pidgin and Creole Languages 14:1-44.

Siegel, Jeff. 2008. The Emergence of Pidgin and Creole Languages. Oxford: Oxford University Press.

Sippola, Eeva. 2013. Ternate Chabacano structure dataset. In Susanne Maria Michaelis, Philippe Maurer, Martin Haspelmath, and Magnus Huber (eds.), Atlas of Pidgin and Creole Language Structures Online. Leipzig: Max Planck Institute for Evolutionary Anthropology. http://apics-online.info/ (accessed June 7, 2016).

Slomanson, Peter. 2013. Sri Lankan Malay structure dataset. In Susanne Maria Michaelis, Philippe Maurer, Martin Haspelmath, and Magnus Huber (eds.), Atlas of Pidgin and Creole Language Structures Online. Leipzig: Max Planck Institute for Evolutionary Anthropology. http://apics-online.info/ (accessed June 7, 2016).

Smith, Geoff P. and Jeff Siegel. 2013a. Tok Pisin structure dataset. In Susanne Maria Michaelis, Philippe Maurer, Martin Haspelmath, and Magnus Huber (eds.), Atlas of Pidgin and Creole Language Structures Online. Leipzig: Max Planck Institute for Evolutionary Anthropology. http://apics-online.info/ (accessed June 7, 2016).

Smith, Geoff P. and Jeff Siegel. 2013b. Tok Pisin. In Susanne Maria Michaelis, Philippe Maurer, Martin Haspelmath, and Magnus Huber (eds.). The Survey of Pidgin and Creole Language, 3 volumes, 214-222. Oxford: Oxford University Press. 
van den Berg, Margot and Adrienne Bruyn. 2013. Early Sranan structure dataset. In Susanne Maria Michaelis, Philippe Maurer, Martin Haspelmath, and Magnus Huber (eds.), Atlas of Pidgin and Creole Language Structures Online. Leipzig: Max Planck Institute for Evolutionary Anthropology. http://apics-online.info/ (accessed June 7, 2016).

Velupillai, Viveka. 2012. An Introduction to Linguistic Typology. Amsterdam / Philadelphia: John Benjamins.

Velupillai, Viveka. 2013. Hawai'i Creole structure dataset. In Susanne Maria Michaelis, Philippe Maurer, Martin Haspelmath, and Magnus Huber (eds.), Atlas of Pidgin and Creole Language Structures Online. Leipzig: Max Planck Institute for Evolutionary Anthropology. http://apics-online.info/ (accessed June 7, 2016).

Velupillai, Viveka. 2015. Pidgin and Creole Languages. An Introduction. Amsterdam / Philadelphia: John Benjamins.

Vitale, Anthony. 1981. Swahili Syntax. Dordrecht: Foris.

Wälchli, Bernhard and Fernando Zúñiga. 20o6. Source-goal (in)difference and the typology of motion events in the clause. Sprachtypologie und Universalienforschung (sTUF) 59:284-303.

Winford, Donald and Ingo Plag. 2013. Sranan structure dataset. In Susanne Maria Michaelis, Philippe Maurer, Martin Haspelmath, and Magnus Huber (eds.), Atlas of Pidgin and Creole Language Structures Online. Leipzig: Max Planck Institute for Evolutionary Anthropology. http://apics-online.info/ (accessed June 7, 2016).

Winford, Donald and Bettina Migge. 2007. Substrate influence on the emergence of the TMA systems of the Surinamese creoles. Journal of Pidgin and Creole Languages 22:73-99.

Zhang, Guohua. 2013. Mandarin Chinese valency patterns. In Iren Hartmann, Martin Haspelmath, and Bradley Taylor (eds.), Valency Patterns Leipzig. Leipzig: Max Planck Institute for Evolutionary Anthropology. http://valpal.info/languages/man darin (accessed September 21, 2015). 